\title{
Determining the Effectiveness of the Process Genre Approach in Increasing and Decreasing Saudi EFL University Students' Complexity, Accuracy, and Fluency in Reaction Essays
}

\author{
Talal Musaed Alghizzi ${ }^{1} \&$ Tahani Munahi Alshahrani ${ }^{1}$ \\ ${ }^{1}$ English Language Department, College of Languages and Translation, Al Imam Mohammad Ibn Saud Islamic \\ University, Riyadh, Saudi Arabia \\ Correspondence: Talal Musaed Alghizzi, English Language Department, College of Languages and Translation, \\ Al Imam Mohammad Ibn Saud Islamic University, Riyadh, Saudi Arabia. E-mail: tmalghizzi@imamu.edu.sa
}

Received: October 19, 2019

Accepted: December 14, 2019 Online Published: January 20, 2020

doi:10.5539/ijel.v10n1p424

URL: https://doi.org/10.5539/ijel.v10n1p424

\begin{abstract}
This study investigates the level of effectiveness that the process genre approach has on increasing and decreasing Saudi advanced EFL undergraduates' Complexity, Accuracy, and Fluency (CAF) in reaction writing. Sixteen level six participants were recruited from the College of Languages and Translation at Al-Imam Muhammad Ibn Saud Islamic University. All participants undertook a pre-test and a post-test on reaction writing. After collecting 32 essays, they were analyzed based on 55 indices of CAF, and then a Wilcoxon Signed-Rank Test was applied to compare each CAF construct/sub-construct measure's mean in the pre-test with its mean in the post-test, and between the total mean of all measures for each CAF construct/sub-construct in the pre-test with their total means in the post-test. The findings showed that there were no significant total or partial impacts of the process genre approach on participants' reaction essay syntactic complexity, lexical density, lexical sophistication, and fluency. However, the results indicated that there were only partial effects of the approach (across some measures) on participants' reaction essay lexical variation and accuracy. Finally, the study yields several pedagogical implications and recommendations for EFL writing instructors, educators, and researchers.
\end{abstract}

Keywords: writing, complexity, accuracy, fluency, process genre approach, EFL learners

\section{Introduction}

\subsection{The Importance of the Process Genre Approach and CAF Measures}

In recent years, studies dedicated to EFL writing have been growing in number due to the rapid orientation of the importance of learning English in Arab countries. Since this field is recognized as a promising and distinctive terrain in applied linguistics, it begins to occupy the center of EFL research. In fact, EFL researchers constantly seek to develop writing as it is considered one of the most vital skills in the English language. The recent surge of interest in EFL writing leads researchers to investigate and develop approaches to improve and trace learners' writing development (Voon, 2007). To achieve a good command of linguistic knowledge and improve contextual knowledge, researchers (Pourdana \& Behbahani, 2012; Yang \& Sun, 2015; Zhang, 2018) advocate the use of the process genre approach. Arteaga-Lara (2017) argued that the process genre approach is the most practical approach that can be demonstratively adopted in writing courses.

Writing is a task that requires practicing and acquiring a set of structures that improve the development of learners' CAF in the target language (Pourdana \& Behbahani, 2012). Lambert and Kormos (2014) reported that one of the research topics currently attracting the attention of EFL researchers is how to investigate the development of EFL learners' writing in terms of CAF. For this reason, the current study explored the impact of the process genre approach on developing CAF aspects of Saudi EFL learners' reaction essays. Thus, CAF constructs and sub-constructs were used to measure learners' progress through using the process genre approach as a strategy for teaching writing.

As a matter of fact, no one ignores the importance of developing English writing skills since it is considered one of the fundamental goals of the colleges/departments of English in Saudi Arabia. Therefore, it is sensible to expose learners to the best methods that are thought to improve performance. Al Fadda (2012) argued that, though there are some noticeable efforts to develop learners' writing skills, it seems that Saudi learners lack 
some of the fundamental aspects of writing English. She maintained that numerous studies support the fact that those learners suffer from problems in composing a well-organized piece of text. Alghizzi (2017) emphasized that, though EFL instructors are constantly trying to develop EFL writers, their efforts are limited to examining, for example, the impact of applying various types of tools (e.g., blogs, mind-mapping software, websites), contexts (e.g., traditional, blended, and virtual classrooms), and supplementary materials (e.g., Alnufaie \& Grenfell, 2012; Bukhari, 2016; Fageeh, 2011; Grami, 2012; McMullen, 2009; Sayed, 2010). Additionally, in another study, Alghizzi (2012) confirmed that Saudi EFL instructors do not employ a specific writing approach to teach writing. Instead, they followed a combination of different methods to accomplish the task.

McMullen (2009) confirmed that writing instructors and EFL learners in Saudi Arabia face difficulties regarding the development of writing skills. He also noted that many Saudi writing instructors agreed that writing "always represent[s] a unique challenge [for them and] for Saudi EFL students" (p. 418). Alghizzi (2017) claimed that, in order to overcome difficulties related to EFL writing skills, research should address issues related to teaching and learning contexts and approaches related to the development of CAF constructs and sub-constructs. According to him, such an approach to study would provide educators with ways to deal with learners' weaknesses and track their development through the learning process.

\subsection{Statement of the Problem}

It can be seen from the aforementioned points that there are three main problems that may justify the intention to start such a valuable investigation of EFL learners' CAF development. First, teaching writing in Saudi is not usually assigned to writing specialists. The reason for this is that all instructors should reach the quorum assigned to faculty (16 hours), and, therefore, some faculty teach writing not because they really want to, but because they must fulfill their quorum. As a result, this would eliminate learners' self-autonomy towards writing and increase EFL learners' writing weaknesses (Alghizzi, 2012, 2017). Second, which is also related to the generally inexperienced EFL writing instructors, is that they typically employ the common methods for assessing writing: analytic and holistic. According to Hosseini and Mowlaie (2016), holistic scoring requires evaluators to read the paper and then rate it as a whole, assigning single scores based on an impression. This method is criticized for being subjective and for scores not being justified. Moreover, there is no feedback for the learner. As for the analytic method of assessment, raters develop specific criteria for evaluating the text in light of discrete components such as content, organization, vocabulary, grammar, and mechanics (e.g., Jacob, Zingraf, Warmuth, Hartfiel, \& Hughey, 1981). Some researchers criticize the analytic method for being time-consuming, subjective, isolating features from the context, and focusing on specified aspects of the performance, which require raters to concentrate on the part rather than the whole. Alghizzi (2017) emphasized that the two methods fail to specify the levels of development of students' writing ability in the light of CAF constructs.

The third issue related to conducting this study is that there is a paucity of research on tracing the writing development of EFL learners' CAF and its relation to the process genre approach. To be specific, there is almost no research addressing the role of the process genre approach in developing Saudi EFL learners' CAF. In terms of using CAF constructs to investigate Saudi EFL learners' writing development, there is only one study, undertaken by Alghizzi (2017), who traced the development of CAF in L2 writing using different writing contexts: blended learning, traditional learning, and online learning. Arteaga-Lara (2017) argued that studies that take into account EFL learners' CAF development with regard to powerful approaches, such as the process genre approach, are much scarcer.

\subsection{Relevant Related Literature}

There has been some debate among researchers over defining the term writing. For Hammad (2014), writing is a process that "involves a series of forward and backward movements between the writer's ideas and the written text" (p. 1). Şahin (2010) confirmed that writing is "a behavior including various closely interrelated complex skills such as punctuation, handwriting, spelling, creativity, and self-expression as well as specific writing components such as grammar, mechanics, production, order of writing, linguistics, and understanding" (p. 777). Coulmas (2003) contended that the difficulty in defining writing is related to its long history, its importance, and the multiple meanings of English words. Yi (2009) argued that defining writing may depend on the experience of some teachers, educators, or researchers, the context (situation, setting, task and materials), the goal of the method, or learners' characteristics.

Alghizzi (2017) confirmed that numerous approaches have been suggested to teach EFL learners (e.g., the Audio-Lingual Method, Suggestopedia, the Silent Way, the Communicative Approach, Community Language Learning, and the Comprehension Approach). However, teaching English in the Arab world currently depends on only one or two of these approaches. Moreover, Al-Seghayer $(2014,2015)$ claimed that the Grammar Translation 
and the Audio-Lingual approaches are among the top used methods in Saudi Arabia. He emphasized that these approaches have proven to be insufficient for improving EFL learners because they encourage the use of translation, drilling and memorization. According to Alghizzi (2011, 2012), the constant use of these approaches in teaching writing would constitute robust evidence for EFL learners' weaknesses. He also noted that the native language is used as the medium of instruction, which contributes to the development of some serious linguistic problems such as applying Arabic structures to English writing (cf. Al-Nofaie, 2010). Furthermore, Alghizzi $(2011,2012)$ claimed that Saudi EFL instructors do not actively use approaches that are pedagogically designed to teach writing. Such approaches are described in detail below.

\subsubsection{Writing Approaches}

Though a vast number of approaches have been proposed to develop EFL learners, Nunan (2000) emphasized that process and product approaches are among the most commonly used writing approaches. The product approach, which emerged first, views learners as passive individuals who are expected to respond to the teacher's instructions. The principles of this approach were derived from the behaviorist approach in which learners should produce an accurate text based on the imitation of teachers' input. Nunan (2000) maintained that linguistic knowledge is greatly emphasized but imagination and innovative ideas are neglected in this approach. As a reaction to the product approach, Swales (1990) recommended the use of the process approach, which values learners' participation and the composition of ideas. This approach is based on communicative theory and cognitive psychology, which greatly encourage the role of learners' engagement in the classroom. However, a key disadvantage of this approach is that it enhances writing fluency at the expense of other linguistic skills and writing mechanics (Swales, 1990).

In the same vein, in the 1980s, another approach appeared, the genre approach, and this emphasized the role of communicative purposes in social and cultural contexts (Swales, 1990). In this approach, the instructor is dominant in the classroom and directs learners' compositions. The text formats, styles and conventions for a given genre are foregrounded in this style of instruction. Badger and White (2000) criticized this approach for disregarding the basic writing requirements: accuracy and linguistic knowledge. They then proposed a new approach that combined the fruitful elements of the previously mentioned approaches: the process genre approach. This approach maximizes the use of linguistic knowledge, contextual knowledge and writing skills. Thus, linguistic knowledge is connected to contexts and meaningful situations.

Leki, Cumming and Silva (2008) set out five steps for this approach. First, the teacher creates a social situation and the students are asked to figure out its purpose. Then, the teacher presents a model text and explains the structure of the text and how is it constructed to fulfill a communicative situation. Following this, the teacher directs the students' attention to both linguistic and contextual knowledge in the text. Now, students are able to form their own ideas into written texts. Finally, students are expected to produce their final draft in light of teachers' feedback. According to Zhang (2018), these steps enable students to concentrate on language, content and contexts. Moreover, this approach incorporates learner-centered learning that encourages effective communication between the teacher and students and which enables the teacher to identify learners' needs. Zhang (2018) maintained that this way of working would contribute effectively to providing students with confidence and positive attitudes toward writing skills.

These pioneering studies concerning the process genre approach, carried out by linguistics researchers, have inspired EFL applied linguistics research. EFL writing development research has reported the effectiveness of the process genre approach in enhancing the writing competence of EFL learners (e.g., Babalola, 2012; Garnica \& Torres, 2015; Handayani \& Siregar, 2013; Tuyen, Osman, Dan, \& Ahmad, 2016; Voon, 2007). For example, Arteaga-Lara (2017) conducted a study to examine the effectiveness of the process genre approach for developing fourth grade EFL learners in writing narrative paragraphs. By analyzing learners' essays, the findings supported the role of the process genre approach in improving EFL learners' writing. Additionally, Zhang (2018) investigated the change in EFL learners' levels of self-efficacy in process genre academic writing instruction. During a period of 14 weeks, 59 students participated in the study. Results showed that participants' self-efficacy improved significantly.

\subsubsection{Complexity, Accuracy and Fluency}

Housen and Kuiken (2009) argued that diverse elements can be traced in learners' development in learning writing, such as CAF constructs. They maintained that the three constructs are believed to represent essential criteria for assessing learners' written and oral productions. As such, they can be used as an effective indicator of EFL learners' development. Different definitions have been proposed for CAF constructs by many researchers, but these definitions seem to fail to provide a straightforward overview of what may constitute the constructs. 
Norris and Ortega (2009) admitted that "researchers have not done sufficient thinking about what [they] are measuring and why" (p. 560). Alghizzi (2017) argued that these definitions do not actually provide a thorough understanding of CAF constructs for two reasons: 1) they lack some theoretical basis and 2) they cannot be used for both speaking and writing.

The term complexity, the first construct, is identified by many researchers as a difficult term to define for being multidimensional and being subject to varying interpretations. For example, Bulté and Housen (2015) stated that "there is no commonly accepted definition of complexity" (p. 22). In this study, complexity is interpreted with respect to two dimensions: syntactic complexity and lexical complexity. According to Wolfe-Quintero, Inagaki, and Kim (1998), syntactic complexity "means that a wide variety of both basic and sophisticated structures are available and can be accessed quickly, whereas a lack of complexity means that only a narrow range of basic structures are available or can be accessed" (p. 69). Ortega (2003) viewed syntactic complexity as "the range of forms that surface in language production and the degree of sophistication of such forms" (p. 492). As for lexical complexity, Wolfe-Quintero et al. (1998) defined it as when "a wide variety of basic and sophisticated words are available and can be accessed quickly, whereas a lack of complexity means that only a narrow range of basic words are available or can be accessed" (p. 102). In fact, there was no agreement between researchers regarding what to include or exclude in defining the term. However, the term lexical complexity can be best interpreted according to these sub-constructs: lexical density, lexical sophistication, and lexical diversity (Alghizzi, 2017). Bulté and Housen (2015) defined lexical density as the number of lexical words divided by the total number of words. As for lexical sophistication, this refers to the percentage of sophisticated words in a text. The third sub-construct, lexical variation, "can be measured by the simple type/token ratio (TTR)" (Lindqvist, Gudmundson, \& Bardel, 2013, p. 11).

The second construct, accuracy, is generally related to competence in using the grammatical rules of the language. Ellis (2003) argued that accuracy is "the extent to which the language produced in performing a task conforms with target language norms" (p. 339). Skehan (1998) assumed that the term refers to the extent to which the language produced follows the target language rules. Some researchers (see de Bot, Lowie, \& Verspoor, 2007; Verspoor, De Bot, \& Lowie, 2011) think that accuracy is more related to the accurate use of specific forms in a language. The last construct, fluency, is defined by Pourdana and Behbahani (2012) as learners' capability to produce language without any pauses or hesitations. Hence, it can be assessed by measuring the length of the run, pause length, and false starts or repetitions. According to Abdel Latif (2013), writing fluency refers to the "ability to produce texts in large chunks or spans and is optimally measured through using the length of writers' translating episodes or production units" (p. 104). Dobao (2012) confirmed that fluency is the "length of the text" (p. 47). Polio (2001) argued that fluency of writing can be measured by comparing the text to the performance of native speakers. Nonetheless, these constructs and sub-constructs are defined, in this study, according to the writing measures employed in the methodology.

Skehan (1998) confirmed that most research that employs CAF (either separated or in combination) to develop EFL learners tackles topics either related to second language acquisition or performance testing. Recent research, nonetheless, has activated the use of CAF in terms of longitudinal development or has premised CAF as within a dynamic systems theory framework (Vercellotti, 2015). For instance, Pourdana and Behbahani (2012) intended to explore the effect of three types of language assessment tasks (Topic Writing, Picture Description, and Text Reconstruction) on developing the accuracy, fluency and complexity of Iranian EFL learners' writing skills. An Analysis of Variances (ANOVA) revealed that a higher degree of accuracy and complexity was noticed when the participants were actively engaged in Topic Writing tasks, and fluency increased when they were engaged in Picture Writing tasks.

Yang and Sun (2015) conducted a longitudinal study to explore the development of CAF in five undergraduate multilingual learners' writing throughout an academic year. Results showed that CAF measurements can be used as valid indices of multilingual development. Another recent study was undertaken by Ahmadi and Meihami (2017) which investigated the developmental trajectories of CAF in ESP learners' writing ability in two conditions: using topical knowledge, and general knowledge, from a dynamic systems theory perspective. The findings showed that complexity development remained the same in both conditions: general knowledge and topical knowledge. Nonetheless, learners had a higher index of accuracy and fluency in topical essays. As for the Saudi context, Alghizzi (2017) investigated the role of four factors: proficiency levels, text types, time scales, and learning environments on the writing complexity, accuracy, and fluency of EFL Saudi learners. The CAF constructs were used to track the writing skills development of 6 groups of EFL learners under three conditions: Traditional Learning Context (TLC), Blended Learning Context (BLC), and Online Learning Contexts (OLC). The learners' essays were analyzed using two statistical tests: t-test and ANOVA. The results showed that 
proficiency levels and the three learning contexts (TLC, BLC, OLC) produced different effects on improving CAF constructs in both writing tasks.

\subsection{Research Questions}

1) To what extent is the process genre approach effective in developing/deteriorating Saudi advanced EFL undergraduates' syntactic complexity when writing reaction essays?

2) To what extent is the process genre approach effective in developing/deteriorating Saudi advanced EFL undergraduates' lexical complexity when writing reaction essays?

3) To what extent is the process genre approach effective in developing/deteriorating Saudi advanced EFL undergraduates' accuracy when writing reaction essays?

4) To what extent is the process genre approach effective in developing/deteriorating Saudi advanced EFL undergraduates' fluency when writing reaction essays?

\section{Method}

\subsection{Participants}

Initially, 29 students registered for the level six Eng.316 course. However, towards the mid-point of the semester, 13 participants withdrew from the course, possibly because they could not handle the requirements of the applied teaching approach (i.e., process genre). Demographically, the ages of the remaining 16 participants ranged from 20 to 29 and the length of their exposure to English ranged from 13 to 16 years. The proficiency level of these participants was determined to be advanced, not only because of course requirements (no student is permitted to register unless they have already finished five other writing courses), but also because of the participants' academic level, level six. Wolfe-Quintero et al. (1998, p. 9) emphasized that program levels may be, developmentally speaking, the best indicators of students' actual proficiency levels in comparison to other proficiency measures. The reason for this is that no student can transfer from their current assigned program level to the following level without increasing their current proficiency level.

\subsection{Research Design and Settings}

At the College of Languages and Translation, at Al-Imam Mohammad Ibn Saudi Islamic University, one of the researchers was assigned a group of students undertaking an essay writing course (Eng.316) for two hours weekly. As it was infeasible to divide this group into two, and thus to recruit a set of people that would serve as a control group, a quasi-experimental pre-test and post-test design was deemed the most suitable. The application of the experiment spanned one whole semester (approximately four months).

\subsection{Ethical Considerations}

Some ethical considerations were emphasized and addressed in this study. For example, at the beginning of the experiment, all participants received detailed instructions on the course's teaching approach, requirements, supplementary materials, the importance of CAF measures for tracing writing development, etc. They were also told that their participation is voluntary, and if they decided not to proceed with it, they would be transferred to any other writing classes of their choice. Moreover, because participants were instructed to write their names in the pre-test and post-test to trace the developments of their writing abilities, they were assured that their names will remain confidential.

\subsection{Materials}

The designated writing textbook for this course was 'Effective Academic Writing 3: The Researched Essay' by Liss and Davis (2012, see Appendix A). The textbook consists of six chapters: The Researched Essay, Comparison-Contrast Essays, Cause-and-Effect Essays, Argumentative Essays, Classification Essays, and Reaction Essays, and students were only required to study the last three chapters.

\subsection{Teaching Approach and Data Collection Procedures}

In the first lecture with the participants, the writing instructor distributed a course syllabus (see Appendix B) that explained in detail the required textbook, the teaching approach (i.e., process genre as described in detail by Badger \& White, 2000), the supplementary materials, the topics covered, the assignments and activities, the distribution of the marks, as well as the test dates. Participants were told that the allocated time for their mid-term test would be postponed to the last week before the final exams to serve as a post-test for the experiment. At the beginning of the second week lecture, a pre-test was distributed among participants and, for fifty minutes, they were required to write a 250 -word essay on the question: can children become aggressive as a result of playing violent games? Then, each pre-test was photocopied twice, one copy of which was corrected 
and commented on-in terms of purpose, register, audience, words, phrases, expressions, sentences, format, style, grammar, organization, clarity, punctuations-by the instructor, while the other was examined by students' colleagues. After each participant received the two corrected copies of the pre-test the following day, they were asked to take into account the identified mistakes/errors and highlighted comments when producing second drafts. All of these drafts had to be submitted to the instructor's mailbox the following day. After applying the same types of corrections (i.e., instructor's and peers' corrections), the above procedures were repeated for the third, fourth, and so on drafts. In each of the following lectures until the end of the experiment, not only were participants exposed to simultaneous detailed presentations on the three text types addressed on the course (reaction argumentative, and classification), but they were also required to analyze ad hoc samples of these text types in terms of purpose, register, audience, words, phrases, expressions, sentences, format, style, grammar, organization, clarity, punctuations, and so forth. Following this, at home, participants were required to write a new essay on given topics that matched the specified text type on the first week (i.e., six and ten) of each five weeks. The text lengths, procedures of writing, editing, revising and submission were similar to those applied to the pre-tests.

In the last week before the final exams, participants undertook their post-test in which a reaction essay question (how did you feel after Saudi Arabia allowed women to drive?) should be written in the form of a 250 -word essay in fifty minutes.

\subsection{Data Analysis}

The total number of essays collected were 45 ; however, 13 of these were discarded as they belonged to the participants who dropped out of the course before undertaking the post-test. The thirty-two essays left were analyzed according to $55 \mathrm{CAF}$ indices: syntactic complexity (11 measures), lexical complexity: lexical density (1 measure), lexical sophistication (5 measures), and lexical variation (19 measures), accuracy (12 measures), and fluency (7 measures). For Wolfe-Quintero et al. (1998), the development of the EFL learners' writing abilities are adequately traced using the measures of these constructs and sub-constructs. Table 1 below presents these measures in greater detail.

Table 1. Measures of syntactic complexity, lexical complexity, accuracy, and fluency

\begin{tabular}{ll}
\hline Constructs & Measures \\
\hline Syntactic & sentence complexity ratio (C/S), T-unit complexity ratio (C/T), complex T-unit ratio (CT/T), dependent clause \\
Complexity & ratio (DC/C), dependent clauses per T-unit (DC/T), coordinate phrases per clause (CP/C), coordinate phrases per \\
& T-unit (CP/T), sentence coordination ratio (T/S), complex nominals per clause (CN/C), complex nominals per \\
& T-unit (CN/T), and verb phrases per T-unit (VP/T) \\
Lexical Complexity & Density: (LD) \\
& Sophistication: lexical sophistication-I (LS1), lexical sophistication-II (LS2), verb sophistication-I (VS1), \\
& corrected VS1 (CVS1), and verb sophistication-II (VS2) \\
& Variation: number of different words (NDW), NDW (first 50 words) (NDWZ), NDW (expected random 50) \\
& (NDWERZ), NDW (expected sequence 50) (NDWESZ), type/token ratio (TTR), mean segmental TTR (50) \\
& (MSTTR), corrected TTR (CTTR), root TTR (RTTR), bilogarithmic TTR (LogTTR), uber index (Uber), lexical \\
& word variation (LV), verb variation-I (VV1), squared VV1 (SVV1), corrected VV1 (CVV1), verb variation-II \\
& (VV2), noun variation (NV), adjective variation (AdjV), adverb variation (AdvV), modifier variation (ModV) \\
& Frequency: errors (E), error-free T-units (EFT), and error-free clauses (EFC) \\
Accuracy & Ratio: errors per word (E/W), errors per T-unit (E/T), errors per clause (E/C), error-free T-units per ratio \\
& (EFT/T), error-free T-units per word (EFT/W), error-free T-units per sentence (EFT/S), error-free clause ratio \\
& (EFC/C), error-free clauses per T-unit (EFC/T), error-free clauses per sentence (EFC/S) \\
& Frequency: words (W), sentences (S), clauses (C), and T-units (T) \\
Fluency & Ratio: mean length of sentences (W/S), mean length of clauses (W/C), and mean length of t-units (W/T) \\
&
\end{tabular}

Both syntactic and lexical complexities were analyzed automatically using online batch modes: Web-based Syntactic Complexity Analyzer (L2SCA [Ai, 2017a]) and Web-based Lexical Complexity Analyzer (LCA [Ai, 2017b]) (Note 1). Crossley and McNamara $(2009,2014)$ contended that automatic analysis software programs such as those mentioned above, in comparison to human raters who are prone to subjectivity and who require time to score, train, and monitor, have not only been developed on sound theoretical approaches, but they also offer speed, reliability, and flexibility-elements very important when analyzing written productions quantitatively. Not surprisingly, both L2SCA and LCA were found reliable and valid in many studies (e.g., Kim, 2014; Long \& Tabuki, 2014; Lu, 2017; Lorenzo \& Rodríguez, 2014; Mazgutova \& Kormos, 2015; Tsai, 2013; 
Yang, 2014; Yoon \& Polio, 2014). However, although L2SCA produced the results of 14 measures, W/S, W/C, W/T measures were transferred to fluency because Wolfe-Quintero et al. (1998) emphasized that all length indices were incapable of explaining how the various production lengths are accomplished.

The rest of the fluency measures, as well as those for accuracy, were analyzed manually (see Appendices $\mathrm{C}$ and D) by applying - if needed - the same definitions of production units and syntactic structures used in L2SCA (Note 2). The types of errors and mistakes calculated in this research are morphological, spelling, grammatical, and capitalization while other types, such as word choice and punctuation were overlooked. The results for all constructs' and sub-constructs' measures were entered in SPSS and then two comparisons were drawn using one statistical test: the Wilcoxon Signed-Rank Test. In the first comparison, the mean of each measure for each construct/sub-construct in the pre-test was compared with the mean of the same measure in the post test. On the other hand, in the second comparison, the total mean of all the measures for every construct/sub-construct in the pre-test was compared with the total mean of all measures for every construct/sub-construct in the post-test.

\section{Results}

\subsection{Syntactic Complexity}

Table 2 presents the syntactic complexity measures' pre-test and post-test comparison results.

Table 2. Syntactic complexity measures' pre-test and post-test comparison results

\begin{tabular}{|c|c|c|c|c|c|}
\hline Syntactic Complexity Measures & Tests & $\mathbf{N}$ & Mean & Standard deviation & Critical value $(\mathrm{Z})$ \\
\hline \multirow[t]{2}{*}{$\mathrm{C} / \mathrm{S}$} & Pre-Test & 16 & 2.08 & 1.07 & 0.38 \\
\hline & Post-Test & 16 & 2.13 & 0.92 & \\
\hline \multirow[t]{2}{*}{$\mathbf{V P} / \mathbf{T}$} & Pre-Test & 16 & 1.92 & 0.45 & 1.13 \\
\hline & Post-Test & 16 & 2.48 & 1.14 & \\
\hline \multirow[t]{2}{*}{$\mathbf{C} / \mathbf{T}$} & Pre-Test & 16 & 1.55 & 0.31 & 1.26 \\
\hline & Post-Test & 16 & 1.89 & 0.87 & \\
\hline \multirow[t]{2}{*}{$\mathrm{DC} / \mathrm{C}$} & Pre-Test & 16 & 0.30 & 0.08 & 1.61 \\
\hline & Post-Test & 16 & 0.36 & 0.13 & \\
\hline \multirow[t]{2}{*}{$\mathrm{DC} / \mathrm{T}$} & Pre-Test & 16 & 0.50 & 0.24 & 1.64 \\
\hline & Post-Test & 16 & 0.78 & 0.58 & \\
\hline \multirow[t]{2}{*}{$\mathbf{T} / \mathbf{S}$} & Pre-Test & 16 & 2.09 & 0.16 & 0.38 \\
\hline & Post-Test & 16 & 2.14 & 0.35 & \\
\hline \multirow[t]{2}{*}{$\mathbf{C T} / \mathbf{T}$} & Pre-Test & 16 & 0.40 & 0.18 & 1.53 \\
\hline & Post-Test & 16 & 0.49 & 0.22 & \\
\hline \multirow[t]{2}{*}{$\mathrm{CP} / \mathrm{T}$} & Pre-Test & 16 & 0.36 & 0.15 & 0.15 \\
\hline & Post-Test & 16 & 0.36 & 0.28 & \\
\hline \multirow[t]{2}{*}{$\mathrm{CP} / \mathrm{C}$} & Pre-Test & 16 & 0.23 & 0.10 & 1.13 \\
\hline & Post-Test & 16 & 0.19 & 0.14 & \\
\hline \multirow[t]{2}{*}{$\mathrm{CN} / \mathrm{T}$} & Pre-Test & 16 & 1.68 & 0.63 & 0.77 \\
\hline & Post-Test & 16 & 1.48 & 0.61 & \\
\hline \multirow[t]{2}{*}{$\mathrm{CN} / \mathrm{C}$} & Pre-Test & 16 & 1.67 & 0.40 & 0.76 \\
\hline & Post-Test & 16 & 1.47 & 0.40 & \\
\hline \multirow[t]{2}{*}{ Syntactic Complexity as a whole } & Pre-Test & 16 & 11.42 & 2.68 & 0.31 \\
\hline & Post-Test & 16 & 12.16 & 4.29 & \\
\hline
\end{tabular}

Note. $(*)$ indicates the significant results at $0.05,(* *)$ indicates the significant results at 0.01 .

The table shows that, in terms of the comparison between the means of each syntactic complexity measure in the pre-test and the post-test, there were no statistically significant differences. The table also reveals that, as regards the comparison of all syntactic complexity measures' total means in the pre-test $(M=11.42)$ with that in the post-test $(\mathrm{M}=12.16)$, there was no statistically significant difference ( $\mathrm{z}$. value $=0.31)$. All of these indicate that the syntactic complexity of Saudi advanced EFL undergraduates neither developed nor deteriorated, neither partially nor as a whole. The construct in participants' reaction essays was not affected by the application of the process genre approach. Figure 1 shows the comparison results for syntactic complexity as a whole. 


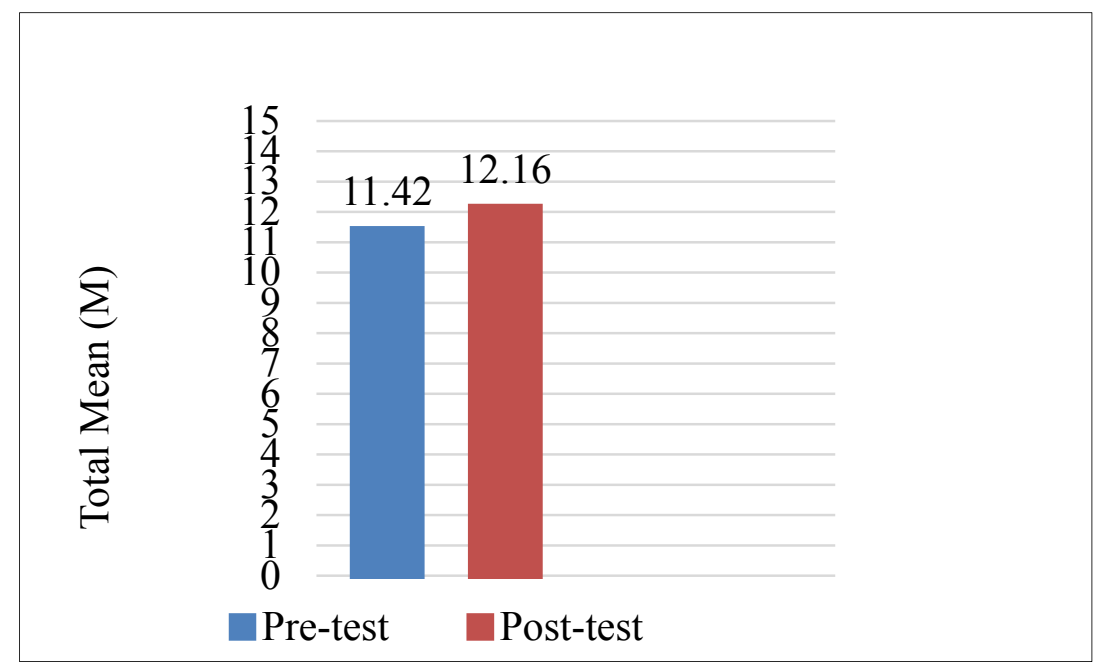

Figure 1. Syntactic complexity as a whole

\subsection{Lexical Complexity}

\subsubsection{Lexical Density and Sophistication}

Table 3 displays lexical density and sophistication measures' pre-test and post-test comparison findings.

Table 3. Lexical density and lexical sophistication measures' pre-test and post-test comparison results

\begin{tabular}{|c|c|c|c|c|c|}
\hline $\begin{array}{l}\text { Lexical Density and Lexical } \\
\text { Sophistication Measures }\end{array}$ & Tests & $\mathbf{N}$ & Mean & Standard deviation & Critical value (Z) \\
\hline \multirow[t]{2}{*}{ LD (Note 3) } & Pre-Test & 16 & 0.51 & 0.03 & 1.47 \\
\hline & Post-Test & 16 & 0.48 & 0.05 & \\
\hline \multirow[t]{2}{*}{ LS1 } & Pre-Test & 16 & 0.29 & 0.10 & 1.06 \\
\hline & Post-Test & 16 & 0.24 & 0.07 & \\
\hline \multirow[t]{2}{*}{ LS2 } & Pre-Test & 16 & 0.19 & 0.04 & 0.17 \\
\hline & Post-Test & 16 & 0.19 & 0.05 & \\
\hline \multirow[t]{2}{*}{ VS1 } & Pre-Test & 16 & 0.10 & 0.08 & 1.44 \\
\hline & Post-Test & 16 & 0.06 & 0.05 & \\
\hline \multirow[t]{2}{*}{ VS2 } & Pre-Test & 16 & 0.33 & 0.37 & 1.10 \\
\hline & Post-Test & 16 & 0.25 & 0.50 & \\
\hline \multirow[t]{2}{*}{ CVS1 } & Pre-Test & 16 & 0.33 & 0.24 & 1.10 \\
\hline & Post-Test & 16 & 0.26 & 0.25 & \\
\hline \multirow[t]{2}{*}{ Lexical Sophistication as a Whole } & Pre-Test & 16 & 1.25 & 0.73 & 1.50 \\
\hline & Post-Test & 16 & 1.02 & 0.82 & \\
\hline
\end{tabular}

Note. $\left({ }^{*}\right)$ indicates the significant results at $0.05,(* *)$ indicates the significant results at 0.01 .

The table shows that across the six measures of the sub-constructs (i.e., lexical density: LD, and lexical sophistication: LS1, LS2, VS1, VS2, and CVS1), there were no statistically significant differences between each measure's mean in the pre-test and the post-test. Similarly, there was no statistically significant difference between the total means of all the lexical sophistication measures in the pre-test $(M=1.25)$ and the post-test ( $M$ $=1.02$ ). The $\mathrm{z}$. value was 1.50. These results mean that the lexical density and lexical sophistication of the Saudi advanced EFL undergraduates did not significantly increase/decrease, either partially or as a whole. These sub-constructs in participants' reaction essays were not impacted by the application of the process genre approach. Figure 2 presents the comparison results for lexical sophistication as a whole. 


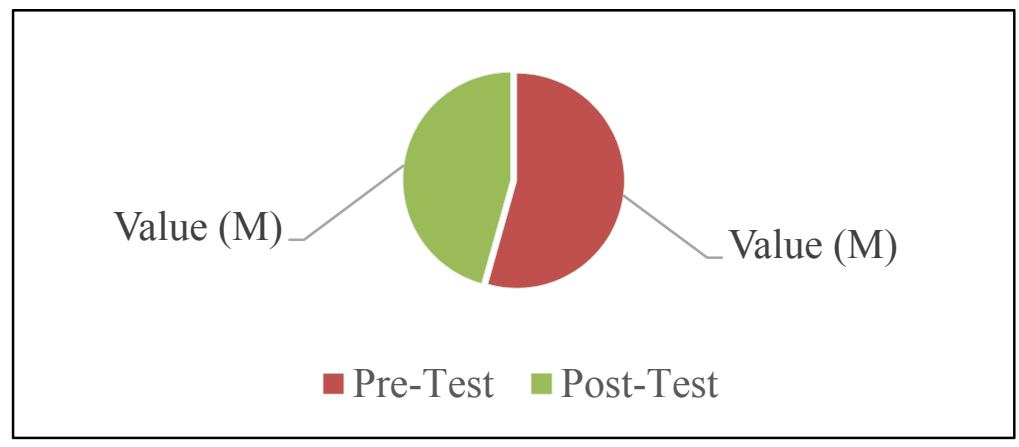

Figure 2. Lexical sophistication as a whole

\subsubsection{Lexical Variation}

Table 4 presents lexical variation measures' pre-test and post-test comparison findings.

Table 4. Lexical variation measures' pre-test and post-test comparison results

\begin{tabular}{|c|c|c|c|c|c|}
\hline Lexical Variation Measures & Tests & $\mathbf{N}$ & Mean & Standard deviation & Critical value (Z) \\
\hline \multirow[t]{2}{*}{ NDW } & Pre-Test & 16 & 104.87 & 39.93 & 0.15 \\
\hline & Post-Test & 16 & 110.68 & 35.36 & \\
\hline \multirow[t]{2}{*}{ NDWZ } & Pre-Test & 16 & 34.25 & 3.60 & 0.79 \\
\hline & Post-Test & 16 & 34.93 & 3.25 & \\
\hline \multirow[t]{2}{*}{ NDWERZ } & Pre-Test & 16 & 35.10 & 3.01 & $2.48 * *$ \\
\hline & Post-Test & 16 & 37.31 & 2.03 & \\
\hline \multirow[t]{2}{*}{ NDWESZ } & Pre-Test & 16 & 34.93 & 3.14 & 1.50 \\
\hline & Post-Test & 16 & 36.51 & 2.27 & \\
\hline \multirow[t]{2}{*}{ TTR } & Pre-Test & 16 & 0.45 & 0.06 & $2.56^{* *}$ \\
\hline & Post-Test & 16 & 0.51 & 0.06 & \\
\hline \multirow[t]{2}{*}{ MSTTR } & Pre-Test & 16 & 0.69 & 0.06 & $1.84 *$ \\
\hline & Post-Test & 16 & 0.72 & 0.04 & \\
\hline \multirow[t]{2}{*}{ CTTR } & Pre-Test & 16 & 4.78 & 0.87 & 1.37 \\
\hline & Post-Test & 16 & 5.23 & 0.65 & \\
\hline \multirow[t]{2}{*}{ Uber } & Pre-Test & 16 & 16.15 & 2.66 & $2.53 * *$ \\
\hline & Post-Test & 16 & 18.79 & 2.51 & \\
\hline \multirow[t]{2}{*}{ LV } & Pre-Test & 16 & 0.71 & 0.16 & 0.62 \\
\hline & Post-Test & 16 & 0.75 & 0.11 & \\
\hline \multirow[t]{2}{*}{ VV1 } & Pre-Test & 16 & 11.36 & 7.18 & 1.60 \\
\hline & Post-Test & 16 & 16.62 & 8.14 & \\
\hline \multirow[t]{2}{*}{ SVV1 } & Pre-Test & 16 & 2.27 & 0.73 & 1.60 \\
\hline & Post-Test & 16 & 2.80 & 0.70 & \\
\hline \multirow[t]{2}{*}{ CVV1 } & Pre-Test & 16 & 0.58 & 0.09 & $3.13 * *$ \\
\hline & Post-Test & 16 & 0.70 & 0.08 & \\
\hline \multirow[t]{2}{*}{ VV2 } & Pre-Test & 16 & 0.12 & 0.04 & $3.07 * *$ \\
\hline & Post-Test & 16 & 0.19 & 0.04 & \\
\hline \multirow[t]{2}{*}{ NV } & Pre-Test & 16 & 0.50 & 0.13 & $3.15^{* *}$ \\
\hline & Post-Test & 16 & 0.67 & 0.11 & \\
\hline \multirow[t]{2}{*}{ AdjV } & Pre-Test & 16 & 0.12 & 0.04 & 0.00 \\
\hline & Post-Test & 16 & 0.13 & 0.05 & \\
\hline \multirow[t]{2}{*}{ RTTR } & Pre-Test & 16 & 6.77 & 1.23 & 1.37 \\
\hline & Post-Test & 16 & 7.40 & 0.93 & \\
\hline \multirow[t]{2}{*}{$\log T T R$} & Pre-Test & 16 & 0.85 & 0.02 & $2.45 * *$ \\
\hline & Post-Test & 16 & 0.87 & 0.01 & \\
\hline \multirow[t]{2}{*}{ AdvV } & Pre-Test & 16 & 0.06 & 0.02 & 1.64 \\
\hline & Post-Test & 16 & 0.08 & 0.04 & \\
\hline \multirow[t]{2}{*}{ ModV } & Pre-Test & 16 & 0.20 & 0.04 & 0.031 \\
\hline & Post-Test & 16 & 0.20 & 0.09 & \\
\hline \multirow[t]{2}{*}{ Lexical Variation as a Whole } & Pre-Test & 16 & 254.83 & 58.01 & 0.931 \\
\hline & Post-Test & 16 & 275.20 & 46.25 & \\
\hline
\end{tabular}

Note. $(*)$ indicates the significant results at $0.05,(* *)$ indicates the significant results at 0.01 . 
In terms of lexical sophistication, the table presents 19 measures. There were some statistically significant differences between the means of NDWERZ $(M=35.10)$, TTR $(M=0.45)$, MSTTR $(M=0.69)$, LogTTR $(M=$ $0.85)$, Uber $(\mathrm{M}=16.15)$, CVV1 $(\mathrm{M}=0.58)$, VV2 $(\mathrm{M}=0.12)$, and $\mathrm{NV}(\mathrm{M}=0.50)$ in the pre-test with their means in the post-test: NDWERZ $(M=37.31)$, TTR $(M=0.51)$, MSTTR $(M=0.72), \operatorname{LogTTR}(M=0.87)$, Uber $(\mathrm{M}=18.79), \mathrm{CVV} 1(\mathrm{M}=0.70)$, VV2 $(\mathrm{M}=0.19)$, and NV $(\mathrm{M}=0.67)$. The $\mathrm{z}$. values were: $2.48,2.56,1.84,2.45$, $2.53,3.13,3.07,3.15$, respectively. On the contrary, there was no statistically significant difference between the total mean of all measures in the pre-test $(\mathrm{M}=254.83)$ and that in the post-test $(\mathrm{M}=275.20)$. The $\mathrm{z}$. value was (0.93). Although there was no significant development/deterioration of lexical variation as a whole in the Saudi advanced EFL undergraduates' productions, the significant increases for some individual measures indicate that the sub-construct was partially affected by the application of the process genre approach in the participants' reaction essays. Figure 3 shows the comparison results for lexical variation as a whole.

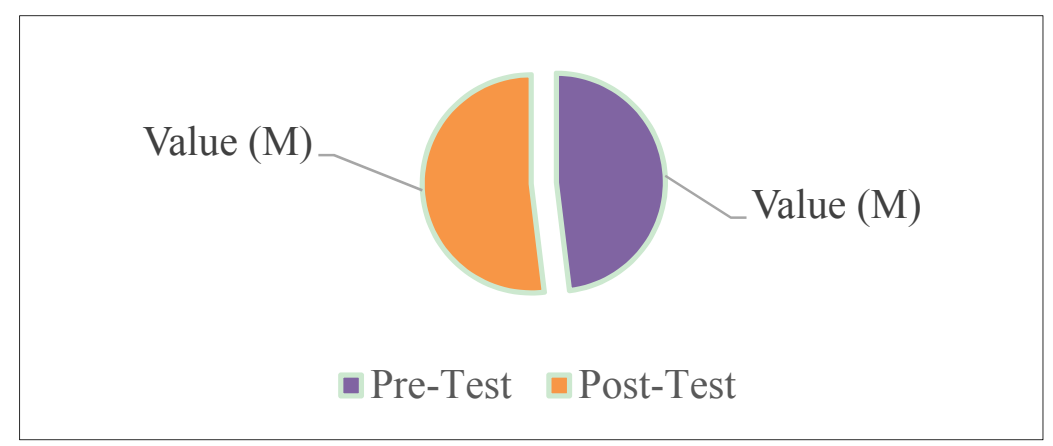

Figure 3. Lexical variation as a whole

\subsection{Accuracy}

Table 5 displays accuracy measures for pre-test and post-test comparison findings.

Table 5. Accuracy measures for pre-test and post-test comparison results

\begin{tabular}{|c|c|c|c|c|c|}
\hline Accuracy Measures & Tests & $\mathbf{N}$ & Mean & Standard deviation & Critical value (Z) \\
\hline \multirow[t]{2}{*}{$\mathbf{E}$} & Pre-Test & 16 & 15.18 & 9.34 & $1.86^{*}$ \\
\hline & Post-Test & 16 & 8.68 & 6.04 & \\
\hline \multirow[t]{2}{*}{ EFT } & Pre-Test & 16 & 8.74 & 6.52 & 0.315 \\
\hline & Post-Test & 16 & 8.31 & 8.34 & \\
\hline \multirow[t]{2}{*}{$\mathbf{E} / \mathbf{T}$} & Pre-Test & 16 & 1.06 & 0.67 & 1.24 \\
\hline & Post-Test & 16 & 0.85 & 1.13 & \\
\hline \multirow[t]{2}{*}{ EFT/T } & Pre-Test & 16 & 0.48 & 0.24 & 0.62 \\
\hline & Post-Test & 16 & 0.45 & 0.29 & \\
\hline \multirow[t]{2}{*}{ EFT/W } & Pre-Test & 16 & 0.03 & 0.01 & 0.10 \\
\hline & Post-Test & 16 & 0.03 & 0.02 & \\
\hline \multirow[t]{2}{*}{ EFT/S } & Pre-Test & 16 & 0.59 & 0.25 & 0.73 \\
\hline & Post-Test & 16 & 0.51 & 0.35 & \\
\hline \multirow[t]{2}{*}{$\mathbf{E F C} / \mathbf{T}$} & Pre-Test & 16 & 0.64 & 0.39 & $2.66 * *$ \\
\hline & Post-Test & 16 & 1.10 & 0.45 & \\
\hline \multirow[t]{2}{*}{ EFC/S } & Pre-Test & 16 & 0.80 & 0.46 & $2.17 * *$ \\
\hline & Post-Test & 16 & 1.26 & 0.62 & \\
\hline \multirow[t]{2}{*}{ EFC } & Pre-Test & 16 & 11.37 & 9.52 & $2.17 * *$ \\
\hline & Post-Test & 16 & 16.68 & 11.86 & \\
\hline \multirow[t]{2}{*}{$\mathbf{E} / \mathbf{W}$} & Pre-Test & 16 & 0.07 & 0.04 & $2.48 * *$ \\
\hline & Post-Test & 16 & 0.04 & 0.02 & \\
\hline \multirow[t]{2}{*}{$\mathbf{E} / \mathbf{C}$} & Pre-Test & 16 & 0.66 & 0.41 & $2.17 * *$ \\
\hline & Post-Test & 16 & 0.38 & 0.27 & \\
\hline \multirow[t]{2}{*}{ EFC/C } & Pre-Test & 16 & 0.43 & 0.29 & $2.22 * *$ \\
\hline & Post-Test & 16 & 0.63 & 0.23 & \\
\hline \multirow{2}{*}{ Accuracy as a whole } & Pre-Test & 16 & 40.11 & 13.14 & 0.414 \\
\hline & Post-Test & 16 & 38.98 & 20.84 & \\
\hline
\end{tabular}

Note. $(*)$ indicates the significant results at $0.05,(* *)$ indicates the significant results at 0.01 . 
The table shows that, in terms of the 12 accuracy measures, there were some significant differences between the means of some measures: $\mathrm{E}(\mathrm{M}=15.18), \mathrm{EFC} / \mathrm{T}(\mathrm{M}=0.64), \mathrm{EFC} / \mathrm{S}(\mathrm{M}=0.80), \mathrm{EFC}(\mathrm{M}=11.37), \mathrm{E} / \mathrm{W}(\mathrm{M}=$ $0.07), \mathrm{E} / \mathrm{C}(\mathrm{M}=0.66)$, and $\mathrm{EFC} / \mathrm{C}(\mathrm{M}=0.43)$ in the pre-test with those in the post test: $\mathrm{E}(\mathrm{M}=8.68), \mathrm{EFC} / \mathrm{T}(\mathrm{M}$ $=1.10), \mathrm{EFC} / \mathrm{S}(\mathrm{M}=1.26), \mathrm{EFC}(\mathrm{M}=16.68), \mathrm{E} / \mathrm{W}(\mathrm{M}=0.04), \mathrm{E} / \mathrm{C}(\mathrm{M}=0.38)$, and $\mathrm{EFC} / \mathrm{C}(\mathrm{M}=0.63)$ (Note 4). In contrast, the total means of all measures in the pre-test $(\mathrm{M}=40.11)$ was not significantly different from that in the post-test $(\mathrm{M}=38.98)$. The $\mathrm{z}$. value was 0.414 . These results indicate that, despite accuracy neither developing nor deteriorating as a whole in Saudi advanced EFL undergraduates' writings, the significant development of $\mathrm{EFC} / \mathrm{T}, \mathrm{EFC} / \mathrm{S}, \mathrm{EFC}$, and $\mathrm{EFC} / \mathrm{C}$, and the deterioration of $\mathrm{E}, \mathrm{E} / \mathrm{W}$, and $\mathrm{E} / \mathrm{C}$ show that the construct in the participants' reaction productions was partially affected by the process genre approach. Figure 4 shows the comparison results for accuracy as a whole.

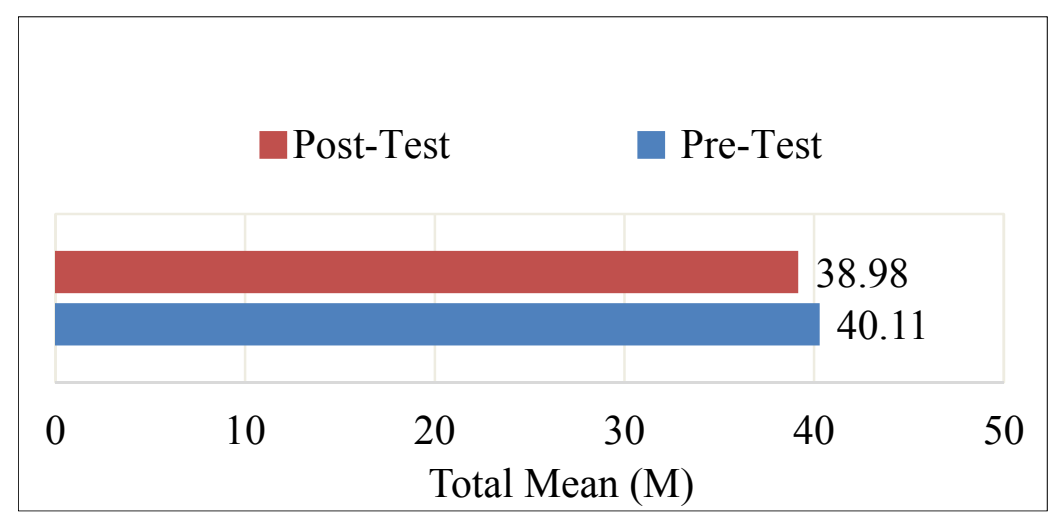

Figure 4. Accuracy as a whole

\subsection{Fluency}

Table 6 presents the fluency comparison results of the Saudi advanced EFL undergraduates in the pre-test and post-test.

Table 6. Fluency measures' pre-test and post-test comparison results

\begin{tabular}{|c|c|c|c|c|c|}
\hline Fluency Measures & Tests & $\mathbf{N}$ & Mean & Standard deviation & Critical value (Z) \\
\hline \multirow[t]{2}{*}{$\mathbf{W}$} & Pre-Test & 16 & 237.43 & 104.11 & 0.31 \\
\hline & Post-Test & 16 & 223.50 & 97.29 & \\
\hline \multirow[t]{2}{*}{$\mathbf{S}$} & Pre-Test & 16 & 13.50 & 5.59 & 0.02 \\
\hline & Post-Test & 16 & 14.25 & 11.69 & \\
\hline \multirow[t]{2}{*}{ C } & Pre-Test & 16 & 24.68 & 7.79 & 0.19 \\
\hline & Post-Test & 16 & 25.12 & 13.30 & \\
\hline \multirow[t]{2}{*}{$\mathbf{T}$} & Pre-Test & 16 & 16.25 & 5.49 & 0.88 \\
\hline & Post-Test & 16 & 15.62 & 11.91 & \\
\hline \multirow[t]{2}{*}{$\mathbf{W} / \mathbf{S}$} & Pre-Test & 16 & 20.36 & 14.43 & 0.05 \\
\hline & Post-Test & 16 & 21.42 & 18.07 & \\
\hline \multirow{2}{*}{$\mathbf{W} / \mathbf{T}$} & Pre-Test & 16 & 15 & 5.22 & 0.20 \\
\hline & Post-Test & 16 & 19.39 & 18.24 & \\
\hline \multirow[t]{2}{*}{$\mathbf{W} / \mathbf{C}$} & Pre-Test & 16 & 9.51 & 2.00 & 1.11 \\
\hline & Post-Test & 16 & 9.47 & 3.86 & \\
\hline \multirow{2}{*}{ Fluency as a whole } & Pre-Test & 16 & 336.75 & 124.25 & 0.41 \\
\hline & Post-Test & 16 & 328.79 & 136.66 & \\
\hline
\end{tabular}

Note. $(*)$ indicates the significant results at $0.05,(* *)$ indicates the significant results at 0.01 .

The table shows that, in the first comparison between the means of each of the seven fluency measures (i.e., W, S, $\mathrm{C}, \mathrm{T}, \mathrm{W} / \mathrm{S}, \mathrm{W} / \mathrm{T}, \mathrm{W} / \mathrm{C}$ ) in the pre-test with their means in the post-test, there were no statistically significant results. Likewise, in the second comparison between the total mean of the constructs for all measures in the pre-test with that in the post-test, there were, again, no statistically significant findings. The lack of a significant 
increase or decrease for the construct indicates that there was no partial or total impact of the process genre approach on the fluency of Saudi advanced EFL undergraduate reaction writing. Figure 5 shows the comparison results for fluency as a whole.

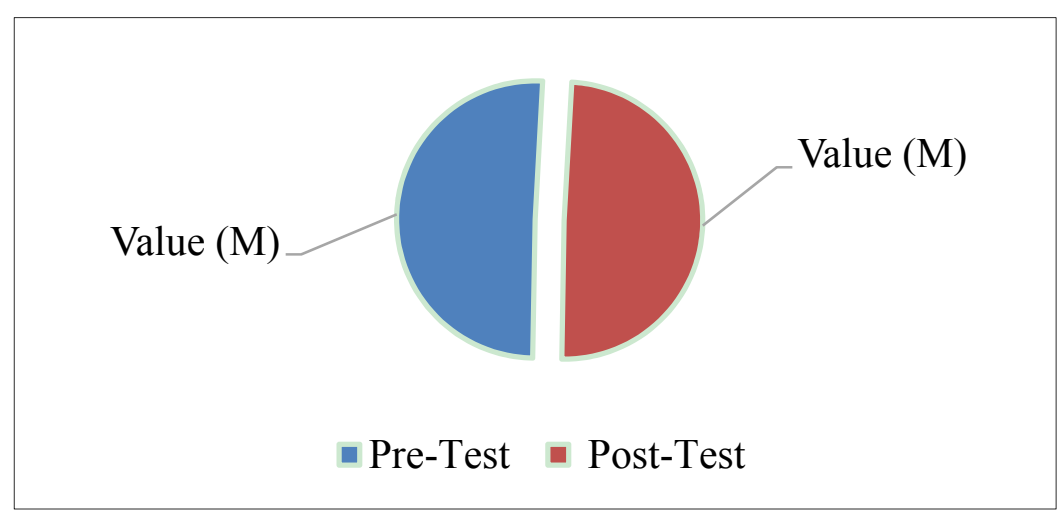

Figure 5. Fluency as a whole

\section{Discussion}

In this study, EFL learners' CAF are explored to discover the role of the process genre approach in developing EFL learners' writing skills. Results strongly suggested that two constructs and sub-constructs (accuracy and lexical variation) improved partially, while the rest (syntactic complexity, lexical density, lexical sophistication and fluency) showed no improvement. The findings of the study can be discussed in light of the role of task complexity along with other factors. Housen and Kuiken (2009) regarded CAF constructs as sufficiently important and meaningful indicators that each needed to be assessed as part of task-based research studies. The relationship between CAF and task complexity would provide an insight into how to understand why some measures increased/decreased as a result of applying the process genre strategy.

For Skehan and Foster (2001) (Note 5), task complexity is the amount of attention the task demands from the participants. Difficult tasks require more attention than easy tasks" (p. 196). According to them, learners make an effort during completing a task which causes some aspects of language to receive more attention than others due to limitations on attention capacity. Such an effect can be extended to include CAF constructs in the process of analyzing writing tasks. The researchers proposed that learners performed better in a simple task than in a complex task. Thus, L2 learners' syntactic complexity, lexical complexity, accuracy, and fluency decreased with difficult tasks due to limited processing capacity, which would then generate a trade-off (mainly) between complexity and accuracy unless some task intervention is provided (this is known as the Limited Attentional Capacity Model [see Note 5]).

On the other hand, Robinson and Gilabert (2007) (Note 6) predicted that learners performed better in a difficult task than in a simple task in which complexity and accuracy both increased, probably at the expense of fluency (the Multiple Attention Resources Model [see Note 6]). In this model, Robinson (2003) discussed two dimensions for task complexity: resource-directing and resource-dispersing. These dimensions affect learners' performance differently. In the resource-directing dimension, Robinson (2003) proposed that learners' complexity and accuracy increased, and their fluency decreased in the complex task, whereas for Skehan and Foster (2001), all CAF constructs would decrease simultaneously. As for the resource-dispersing dimension, both researchers in the two models agreed that learners' CAF would decrease if the task were complex.

The analysis of tasks in this this study from the perspective of the two previously outlined models reflected some incongruity with Skehan and Foster's model, as well as with that of Robinson's. Though the task in the current study is considered to be an easy task which required learners to write a reaction essay in the pre-and-post-test, it was found that, even in the simple task, students had limited attentional capacity, and this led to a trade-off between syntactic complexity, lexical density, lexical sophistication, and fluency on one hand, and lexical variation and accuracy on the other hand. These results are in line with Alghizzi's study (2017), which found that there was a trade-off between CAF constructs though the task provided was rated as easy. This strongly supported the view that EFL learners have limited attentional capacity for both simple and complex tasks. Ellis (2005) supported this claim when he suggested that teachers should provide learners with reasonable tasks as this 
would decrease the attentional load during performance because EFL learners unintentionally focus on some aspects of language and neglect others, which is what leads to the trade-off effect. According to Bamanger and Gashan (2015), EFL learners are usually in a process of learning which reflects the fact that they have limited language proficiency. It is reasonable that they find themselves unable to manage all aspects of language production simultaneously, and, furthermore, in a consistent manner. This would explain to some extent learners' decrease/increase in some CAF sub-constructs in this study.

A thorough examination of each of the CAF constructs can be interpreted according to the circumstances that cause them to either increase or decrease. Results yielded from the data analysis indicate that the process genre approach has no partial or complete impact on complexity, specifically the syntactic complexity, lexical density and lexical sophistication, of advanced Saudi EFL undergraduates. The results seem to be inconsistent with the predictions of Badger and White (2000), who point out the valuable impact of the approach for improving learners' writing skills. Bamanger and Gashan (2015) explained EFL learners' failure to improve in the complexity construct by suggesting that they might not tend to focus on meaning in order to plan the content of their performance and thus fail to produce more complex language. The learners' emphasis during performing the writing task is restricted to excessive attention to grammar and structure. According to Bamanger and Gashan (2015), producing complex language depends heavily on the focus on meaning. However, it has been shown that Saudi EFL learners lack such an element when they are involved in the writing process. For them, pre-task planning time facilitates the processing and planning of the content and the organization of the output.

Ellis (2003) suggested that setting can be considered a factor for developing/deteriorating CAF constructs. Task-based studies (e.g., Alavi, 2017; Rusinovci, 2015; Susser, 1994) that failed to evidence improvement in some CAF constructs reported that the testing context had a significant impact on learners' performance. As a matter of fact, when learners feel that they are being tested, a feeling of anxiety may contaminate the results such that some CAF constructs developed/deteriorated more than others. Ellis (2003) maintained that, when learners feel that they are being tested, this might unconsciously lead them to concentrate more on the accuracy of language at the expense of fluency and complexity.

Given that CAF have already been documented to be the most reliable indicators of language proficiency and language development, the present findings showed that the process genre approach did not yield any noticeable impact on EFL learners' fluency. This is somewhat contradictory to what other researchers found (Badiaa, 2016; Garnica \& Torres, 2015; Gashout, 2014; Rusinovci, 2015; Susser, 1994; Voon Foo, 2007), as they supported the role of the process genre approach in improving EFL learners' writing skills. Skehan and Foster (1999) claimed that achieving development in CAF constructs depends on the requirements of a task. They believe that it is sometimes difficult to strike a balance between these three constructs (CAF) because of different task demands. For instance, some tasks require a focus on structure to enhance accuracy, while others put more emphasis on time in order to improve fluency. It is, therefore, the teachers' responsibility to prepare a task wherein there exists a sort of balance and an appropriate foundation for improving the CAF constructs consistently. In addition, Alavi (2017) emphasized that the purpose of the task plays a significant role in improving learners' fluency, for example, a picture writing task is more appropriate for enhancing fluency while a topic writing task can be the best method for improving accuracy. Thus, it is the instructor's responsibility to choose the appropriate task for improving $\mathrm{CAF}$ constructs.

Bamanger and Gashan (2015) claimed that EFL learners' fluency can be fostered when learners are given some time to prepare before performing a task. Ellis (2003) stated that, when EFL learners are given pre-task planning time, they can invest their time to plan and outline their ideas smoothly. This would significantly reduce the excessive writing load and the difficulties which accompany it. There is no doubt that this approach would help learners to produce well-organized content. Such a claim would explain to some extent the reasons for the failure of the process genre approach to develop fluency of the EFL learners, since they were not given any extra time for preparation before performing some writing tasks.

The present study has shown only a partial impact of the process genre approach on Saudi advanced EFL undergraduates' reactions, production accuracy, and lexical variation. Most of the previously mentioned findings showed that the process genre approach was meaningfully effective in developing the writing skills of EFL learners (e.g., Arteaga-Lara, 2017; Handayani \& Siregar, 2013; Tuyen, Osman, Dan, \& Ahmad, 2016; Voon, 2007; Zhang, 2018). Such partial evidence can be supported by the recent research findings that advocate activating the use of the process genre approach to improve learners' CAF constructs. For example, Arteaga-Lara (2017) examined the effectiveness of the process genre approach in developing fourth grade EFL learners' written narrative paragraphs. The researcher used a pre-test-post-test design to collect his data. The results of the post-test showed that the process genre approach was extremely capable of generating improvement in EFL 
learners.

It can be concluded from the aforementioned results that the effectiveness of the process genre approach is somehow restricted to certain measures within some constructs. Such findings can be somewhat attributed to some participants' characteristics. It seems that those participants were possibly not risk-takers in the sense that they did not try to produce complex syntactic structures, densify their vocabulary or even write sophisticated words. Their chief concern seemed to be accurate production with varied word choices. Another possible reason for the findings is that, during the application of the process genre approach, we focused on correcting students' writing based on criteria such as organization, clarity, grammar, spelling, capitalization, word choice, punctuation, and style, which students would be evaluated against in the final writing exam. Alghizzi (2011, 2012) found that EFL instructors played a major role in terms of the types of mistakes/errors their students would mostly likely identify and correct. Thus, such a factor may be the reason why students only developed partially in terms of accuracy and lexical variation. In other words, because their instructor focused on grammar and word choice, students intentionally tried to produce accurate and varied words in their reaction essay. Further research should be conducted by applying the process genre approach to different text types, proficiency levels, and specific and general CAF measures, and should involve restricting the correction of and comments on students' writing to CAF constructs/sub-constructs.

\section{Conclusion}

In summary, the findings of this study were somewhat contradictory to the previous findings of related studies that supported the effectiveness of the process genre approach (e.g., Badger \& White, 2000; Garnica \& Torres, 2015; Handayani \& Siregar, 2013; Tuyen, Osman, Dan, \& Ahmad, 2016). This study provided conclusive evidence for the approach not being fully efficient in developing EFL learners' CAF. It was found that there was neither a partial nor complete impact of the process genre approach on Saudi advanced EFL undergraduates' syntactic complexity, lexical density, lexical sophistication and fluency in reaction essays. Moreover, there was only a partial impact of the process genre approach on Saudi advanced EFL undergraduates' reactions, production accuracy, and lexical variation. An important implication that can be drawn from this conclusion is that learners' development in CAF constructs is undeniably a dynamic and complicated process, which would offer some valuable insights into the field of L2 writing. Such a dynamic process can be fostered by employing a range of effective writing approaches and strategies to scaffold EFL learners' progress in writing skills. More importantly, during the preparation of what is thought to be an appropriate teaching approach, it is important to measure the complexity of a task in order to attain a considerable improvement in CAF constructs, both simultaneously and equally.

In the endeavor of EFL writing instructors to improve their craft, they almost always search for an ultimate teaching approach that will help develop their students' writing abilities, regardless of the text types they are required to study, the learning environments (i.e., traditional, blended, and distance) they are exposed to, or even their proficiency levels. Many instructors', as well as researchers', understanding of the progression of the writing skill approaches starting from the product approach to the process genre approach led to their inevitable conclusion that only the latter is the most effective.

Therefore, we believe that an artificial view of a particular writing approach is not only ineffective, but will eventually minimize the application of other approaches which may have far greater potential in improving EFL students' writing skills. In order to reconceptualize our understanding of the effectiveness of all writing approaches, we call upon researchers to take the above into consideration while revisiting the other approaches, incorporating different analyses of various text types, proficiency levels, and CAF measures. We believe that it is only at this time that EFL writing instructors will be able to determine what, when, how, and for whom a certain writing approach is effective. Finally, with the limitations of the study in terms of the recruitment of a limited number of participants, the exclusion of a control group comparison, and the involvement of one of the researchers in teaching and rating the participants' written productions, we suggest that the replicate studies of this topic address all of these issues. By doing such, we believe that the generalizability as well as the reliability scopes will be increased.

\section{References}

Abdel Latif, M. M. M. (2013). What do we mean by writing fluency and how can it be validly measured? Applied Linguistics, 34(1), 99-105. https://doi.org/10.1093/applin/ams073

Ahmadi, A., \& Meihami, H. (2017). The development of complexity, accuracy, and fluency in ESP learners' writing: A dynamic systems theory. XLinguae. https://doi.org/10.18355/XL.2017.10.03.05 
Ai, H. (2017a). Web-based L2 syntactical complexity analyzer. Retrieved from $\mathrm{http} / / /$ aihaiyang.com/software/12sca/

Ai, H. (2017b). Web-based lexical complexity analyzer. Retrieved from http://aihaiyang.com/software/lca/

Alavi, S. T. (2017). Development of fluency, accuracy, and complexity in productive skills of EFL learners across gender and proficiency: A chaos complexity approach. Journal of Teaching Language Skills, 35(4), $1-35$.

Al Fadda, H. (2012). Difficulties in academic writing: From the perspective of King Saud University postgraduate students. English Language Teaching, 5(3), 123-130. https://doi.org/10.5539/elt.v5n3p123

Alghizzi, T. M. (2011). The role of English writing instruction methodologies on the types of written mistakes/errors EFL graduate diploma students can identify in their writings. Unpublished graduate diploma thesis. Dublin International Foundation College, Dublin, Ireland.

Alghizzi, T. M. (2012). The role of English writing instruction methodologies on the types of written mistakes/errors Saudi EFL pre-university students can identify in their writings. Unpublished Master's thesis. University College Cork, Cork, Ireland.

Alghizzi, T. M. (2017). Complexity, accuracy, and fluency (CAF) development in L2 writing: the effects of proficiency level, learning environment, text type, and time among Saudi EFL learners. PhD Thesis, University College Cork.

Al-Nofaie, M. (2010). The attitudes of teachers and students towards using Arabic in EFL classrooms in Saudi public schools-A case study. Novitas-ROYAL (Research on Youth and Language), 4(1), 64-95.

Alnufaie, M., \& Grenfell, M. (2012). EFL students' writing strategies in Saudi Arabian ESP writing classes: Perspectives on learning strategies in self-access language learning. Studies in Self-Access Learning Journal, $3(4), 407-422$.

Al-Seghayer, K. (2014). The four most common constraints affecting English teaching in Saudi Arabia. International Journal of English Linguistics, 4(5), 17-26. https://doi.org/10.5539/ijel.v4n5p17

Al-Seghayer, K. (2015). Salient key features of actual English instructional practices in Saudi Arabia. English Language Teaching, 8(6), 89-99. https://doi.org/10.5539/elt.v8n6p89

Arteaga-Lara, H. M. (2017). Using the process-genre approach to improve fourth-grade EFL learners' paragraph writing. Latin American Journal of Content and Language Integrated Learning, 10(2), 217-244. https://doi.org/10.5294/lacli1.2017.10.2.3

Babalola, H. A. (2012). Effects of process-genre based approach on the written English performance of Computer Science students in a Nigerian polytechnic. Journal of Education and Practice, 3(6), 1-6.

Badger, R., \& White, G. (2000). A process genre approach to teaching writing. ELT Journal, 54(2), 153-160. https://doi.org/10.1093/elt/54.2.153

Badiaa, A. (2016). The role of the process approach to improve EFL learners' writing skill: The case of first year master students of English at Biskra University. Master's thesis.

Bamanger, E. M., \& Gashan, A. K. (2015). The effect of planning time on the fluency, accuracy, and complexity of EFL learners' oral production. Journal of Educational Sciences, 27(1), 1-15. https://doi.org/10.33948/1158-027-001-008

Baralt, M., Gilabert, R., \& Robinson, P. (2014). An introduction to theory and research in task sequencing and instructed second language learning. In M. Baralt, R. Gilabert \& P. Robinson (Eds.), Task sequencing and instructed second language learning (pp. 1-34). London: Bloomsbury Academic. https://doi.org/10.5040/9781472593665.ch-001

Bukhari, S. S. F. (2016). Mind Mapping Technique to Enhance EFL Writing Skill. International Journal of Linguistics and Communication, 4(1), 58-77. https://doi.org/10.15640/ijlc.v4n1a7

Bulté, B., \& Housen, A. (2015). Evaluating short-term changes in L2 complexity development. Círculo de Lingüistica Aplicada a la Comunicación, 63, 42-76. https://doi.org/10.5209/rev_clac.2015.v63.50169

Coulmas, F. (2003). Writing systems: An introduction to their linguistic analysis. Cambridge, UK: Cambridge University Press.

Crossley, S. A., \& McNamara, D. S. (2009). Computational assessment of lexical differences in L1 and L2 writing. Journal of Second Language Writing, 18(2), 119-135. https://doi.org/10.1016/j.jslw.2009.02.002 
Crossley, S. A., \& McNamara, D. S. (2014). Does writing development equal writing quality? A computational investigation of syntactic complexity in L2 learners. Journal of Second Language Writing, 26, 66-79. https://doi.org/10.1016/j.jslw.2014.09.006

De Bot, K., Lowie, W., \& Verspoor, M. H. (2007). A dynamic systems theory approach to second language acquisition. Bilingualism: Language and Cognition, 10(1), 7-21. https://doi.org/10.1017/S1366728906002732

Dobao, A. F. (2012). Collaborative writing tasks in the L2 classroom: Comparing group, pair, and individual work. Journal of Second Language Writing, 21(1), 40-58. https://doi.org/10.1016/j.jslw.2011.12.002

Ellis, R. (2003). Task-based language learning and teaching. Oxford: Oxford University Press.

Ellis, R. (2005). Planning and task-based performance: Theory and research. In R. Ellis (Ed.), Planning and task performance in a second language (pp. 3-36). John Benjamins. https://doi.org/10.1075/1llt.11.03ell

Fageeh, A. I. (2011). EFL learners' use of blogging for developing writing skills and enhancing attitudes towards English learning: An exploratory study. Journal of Language and Literature, 2(1), 31-48.

Garnica, V. Y., \& Torres, M. P. (2015). An approximation to writing process through the implementation of a process-genre approach in a blended learning environment. Unpublished Master's thesis. Universidad de La Sabana, Chía, Colombia. Retrieved from http://hdl. handle. net/10818/17456

Gashout, M. (2014). Incorporating the facilitative feedback strategies together with the process approach to improve students' writing. International Journal of Education and Research, 2(10), 637-646.

Grami, G. M. A. (2012). Online Collaborative Writing for ESL Learners Using Blogs and Feedback Checklists. English Language Teaching, 5(10), 43-48. https://doi.org/10.5539/elt.v5n10p43

Hammad, E. A. (2014). Palestinian university students' problems with EFL essay writing in an instructional setting. Journal of Second and Multiple Language Acquisition (JSMULA), 2(1), 1-21. https://doi.org/10.1057/978-1-137-46726-3_5

Handayani, S. W., \& Siregar, M. (2013). Improving students' writing achievement through the process genre approach. Journal of English Language Teaching of FBS Unimed, 2(2), 1-12. https://doi.org/10.24114/reg.v2i2.644

Hosseini, M., \& Mowlaie, B. (2016). Effect of Holistic vs. Analytic Assessment on Improving Iranian Intermediate EFL Learners' Writing Skill. Journal of Language and Translation, 6(1), 11.

Housen, A., \& Kuiken, F. (2009). Complexity, accuracy, and fluency in second language acquisition. Applied Linguistics, 30, 461-473. https://doi.org/10.1093/applin/amp048

Jacobs, H. L., Zinkgraf, S. A., Wormuth, D. R., Hartfiel, V. F., \& Hughey, J. B. (1981). Testing ESL composition; A practical approach. Rowley, MA: Newbury House.

Kim, J.-Y. (2014). Predicting L2 writing proficiency using linguistic complexity measures: A corpus-based study. English Teaching, 69(4), 27-51. https://doi.org/10.15858/engtea.69.4.201412.27

Lambert, C., \& Kormos, J. (2014). Complexity, accuracy and fluency in task-based second language research: toward more developmentally-based measures of second language acquisition. Applied Linguistics, 35(5), 607-614. https://doi.org/10.1093/applin/amu047

Leki, I., Cumming, A., \& Silva, T. (2008). A synthesis of research on second language writing in English. New York: Routledge.

Lindqvist, C., Gudmundson, A., \& Bardel, C. (2013). A new approach to measuring lexical sophistication in L2 oral production.

Long, R., \& Tabuki, M. (2014). Comparing EFL learners and native speaker fluency. In H. Y.-H. Lee (Ed.), Proceedings of the international conference on language and communication: Innovative inquiries and emerging paradigms in language, media and communication (pp. 14-35). Bangkok, Thailand: The Graduate School of Language and Communication and The National Institute of Development Administration.

Lorenzo, F., \& Rodríguez, L. (2014). Onset and expansion of L2 cognitive academic language proficiency in bilingual settings: CALP in CLIL. System, 47, 64-72. https://doi.org/10.1016/j.system.2014.09.016

$\mathrm{Lu}, \mathrm{X}$. (2010). Automatic analysis of syntactic complexity in second language writing. International Journal of Corpus Linguistics, 15(4), 474-496. https://doi.org/10.1075/ijcl.15.4.02lu 
$\mathrm{Lu}, \mathrm{X}$. (2012). The relationship of lexical richness to the quality of ESL learners' oral narratives. The Modern Language Journal, 96(2), 190-208. https://doi.org/10.1111/j.1540-4781.2011.01232.x

$\mathrm{Lu}, \mathrm{X}$. (2017). Automated measurement of syntactic complexity in corpus-based L2 writing research and implications for writing assessment. Language Testing, 34(4), 493-511. https://doi.org/10.1177/0265532217710675

Mazgutova, D., \& Kormos, J. (2015). Syntactic and lexical development in an intensive English for Academic Purposes programme. Journal of Second Language Writing, 29, 3-15. https://doi.org/10.1016/j.jslw.2015.06.004

McMullen, M. G. (2009). Using language learning strategies to improve the writing skills of Saudi EFL students: Will it really work? Science Direct, 37, 418-433. https://doi.org/10.1016/j.system.2009.05.001

Norris, J. M., \& Ortega, L. (2009). Towards an organic approach to investigating CAF in instructed SLA: The case of complexity. Applied Linguistics, 30(4), 555-578. https://doi.org/10.1093/applin/amp044

Nunan, D. (2000). Second language teaching and learning. Beijing: Foreign Language Teaching and Research Press.

Ortega, L. (2003). Syntactic complexity measures and their relationship to L2 proficiency: A research synthesis of college-level L2 writing. Applied Linguistics, 24, 492-518. https://doi.org/10.1093/applin/24.4.492

Polio, C. (2001). Research methodology in second language writing research: The case of text-based studies. In T. Silva \& P. K. Matsuda (Eds.), On second language writing (pp. 91-115). Mahwah, NJ: Lawrence Erlbaum Associates, Inc., Publishers.

Pourdana, N., \& Behbahani, S. M. K. (2012). Task types in EFL context: Accuracy, fluency, and complexity in assessing writing performance. International Journal of Social Science and humanity, 2(1), 80. https://doi.org/10.7763/IJSSH.2012.V2.73

Robinson, P. (2001a). Task complexity, task difficulty, and task production: Exploring interactions in a componential framework. Applied Linguistics, 22(1), 27-57. https://doi.org/10.1093/applin/22.1.27

Robinson, P. (2001b). Task complexity, cognitive resources, and syllabus design: A triadic framework for investigating task influences on SLA. In P. Robinson (Ed.), Cognition and second language instruction (pp. 287-318). Cambridge, UK: Cambridge University Press. https://doi.org/10.1017/CBO9781139524780.012

Robinson, P. (2003). The cognition hypothesis, task design, and adult task-based language learning. Second Language Studies, 21(2), 45-107.

Robinson, P. (2005). Cognitive complexity and task sequencing: Studies in a componential framework for second language task design. IRAL, 43, 1-32. https://doi.org/10.1515/iral.2005.43.1.1

Robinson, P. (2007). Criteria for classifying and sequencing pedagogic tasks. In M. D. P. G. Mayo (Ed.), Investigating tasks in formal language learning (pp. 7-26). Clevedon, UK: Multilingual Matters LTD. https://doi.org/10.21832/9781853599286-004

Robinson, P. (2011a). Task-based language learning: A review issues. In P. Robinson (Ed.), Task-based language learning (pp. 1-36). Sussex, UK: Wiley-Blackwell Publishing. https://doi.org/10.1111/j.1467-9922.2011.00641.x

Robinson, P. (2011b). Second language task complexity, the cognition hypothesis, language learning, and performance. In P. Robinson (Ed.), Second language task complexity: Researching the cognition hypothesis of language learning and performance (pp. 3-37). Amsterdam, The Netherlands: John Benjamins Publishing Company. https://doi.org/10.1075/tblt.2

Robinson, P. (2015). The cognition hypothesis, second language task demands, and the SSARC model of pedagogic sequencing. In M. Bygate (Ed.), Domains and directions in the development of TBLT (pp. 87121). Amsterdam, The Netherlands: John Benjamins Publishing Company. https://doi.org/10.1075/tblt.8.04rob

Robinson, P., \& Gilabert, R. (2007). Task complexity, the cognition hypothesis and second language learning and performance. IRAL, 45, 161-176. https://doi.org/10.1515/iral.2007.007

Rusinovci, X. (2015). Teaching writing through process-genre based approach. US-China Education Review A, 5(10), 699-705. https://doi.org/10.17265/2161-623X/2015.10A.006

Şahin, A. (2010). Effects of jigsaw II technique on academic achievement and attitudes to written expression 
course. Educational Research and Reviews, 5(12), 777-787. https://doi.org/10.1007/s12564-010-9135-8

Sayed, O. H. (2010). Developing Business Management Students' Persuasive Writing through Blog-Based Peer-Feedback. English Language Teaching, 3(3), 54-66. https://doi.org/10.5539/elt.v3n3p54

Skehan, P. (1998). A cognitive approach to language learning. Oxford University Press. https://doi.org/10.1177/003368829802900209

Skehan, P. (2013). Tasks and language performance assessment. In M. Bygate, P. Skehan \& M. Swain (Eds.), Researching pedagogic tasks: Second language learning, teaching and testing (pp. 167-185). Oxon, USA: Routledge Taylor and Francis Group. https://doi.org/10.4324/9781315629766-14

Skehan, P., \& Foster, P. (1997). Task type and task processing conditions as influences on foreign language performance. Language Teaching Research, 1(3), 185-211. https://doi.org/10.1177/136216889700100302

Skehan, P., \& Foster, P. (1999). The influence of task structure and processing conditions on narrative retellings. Language learning, 49(1), 93-120. https://doi.org/10.1111/1467-9922.00071

Skehan, P., \& Foster, P. (2001). Cognition and tasks. In P. Robinson (Ed.), Cognition and second language instruction (pp. 183-205). Cambridge, UK: Cambridge University Press. https://doi.org/10.1017/CBO9781139524780.009

Skehan, P., \& Foster, P. (2005). Strategic and on-line planning: The influence of surprise information and task time on second language performance. In R. Ellis (Ed.), Planning and task performance in a second language (pp. 193-216). Amsterdam, the Netherlands: John Benjamins Publishing Company. https://doi.org/10.1075/1llt.11.12ske

Skehan, P., \& Foster, P. (2012). Complexity, accuracy, fluency, and lexis in task-based performance: A synthesis of the earling research. In A. Housen, F. Kuiken \& I. Vedder (Eds.), Dimensions of L2 performance and proficiency: Complexity, accuracy and fluency in SLA (pp. 199-220). Amsterdam, The Netherlands: John Benjamins Publishing Company. https://doi.org/10.1075/11lt.32.09fos

Susser, B. (1994). Process approaches in ESL/EFL writing instruction. Journal of Second Language Writing, 3(1), 31-47. https://doi.org/10.1016/1060-3743(94)90004-3

Swales, J. M. (1990). Genre analysis: English in academic and research settings. Cambridge: Cambridge University Press.

Tsai, S.-C. (2013). EFL business writing with task-based learning approach: A case study of student strategies to overcome difficulties. K.U.A.S. Journal of Humanities and Social Sciences, 10(2), 217-238.

Tuyen, K. T., Osman, S. B., Dan, T. C., \& Ahmad, N. (2016). Developing research paper writing programs for EFL/ESL undergraduate students using process genre approach. Higher Education Studies, 6(2), 19-29. https://doi.org/10.5539/hes.v6n2p19

Vercellotti, M. L. (2015). The development of complexity, accuracy, and fluency in second language performance: A Longitudinal study. Applied Linguistics, 36(5), 1-23. https://doi.org/10.1093/applin/amv002

Verspoor, M., De Bot, K., \& Lowie, W. (Eds.). (2011). A dynamic approach to second language development: Methods and techniques (Vol. 29). John Benjamins Publishing. https://doi.org/10.1075/1llt.29

Voon, T. (2007). The effects of the process-genre approach to writing instruction on the expository essays of ESL students in a Malaysian secondary school. Unpublished doctoral dissertation. Universiti Sains Malaysia, Penang, Malaysia.

Vurdien, R. (2013). Enhancing writing skills through blogging in an advanced English as a Foreign Language class in Spain. Computer Assisted Language Learning, 26(2), 126-143. https://doi.org/10.1080/09588221.2011.639784

Wolfe-Quintero, K., Inagaki, S., \& Kim, H.-Y. (1998). Second language development in writing: Measures of fluency, accuracy \& complexity. Hawai'i, USA: Second Language Teaching \& Curriculum Center.

Yang, W. (2014). Mapping the relationships among the cognitive complexity of independent writing tasks, L2 writing quality, and complexity, accuracy and fluency of L2 writing. Doctoral dissertation, Georgia State University. Retrieved from https://scholarworks.gsu.edu/cgi/viewcontent.cgi?article=1029\&context=alesl_diss

Yang, W., \& Sun, Y. (2015). Dynamic development of complexity, accuracy and fluency in multilingual learners' L1, L2 and L3 writing. Theory and Practice in Language Studies, 5(2), 298-308. 
https://doi.org/10.17507/tpls.0502.09

Yi, J.-Y. (2009). Defining writing ability for classroom writing assessment in high schools. Pan-Pacific Association of Applied Linguistics, 13(1), 53-69.

Yoon, H. J., \& Polio, C. (2014). A longitudinal study of linguistic complexity in two genres. In Colloquium on Cross-Linguistic aspects of linguistic complexity in second language research. Vrije Universiteit, Brussels (pp. 19-22).

Yuan, F., \& Ellis, R. (2003). The effects of pre-task planning and on-line planning on fluency, complexity and accuracy in L2 monologic oral production. Applied Linguistics, 24(1), 1-27. https://doi.org/10.1093/applin/24.1.1

Zhang, Y. (2018). Exploring EFL learners' self-efficacy in academic writing based on process-genre approach. English Language Teaching, 11(6), 115-124. https://doi.org/10.5539/elt.v11n6p115

\section{Notes}

Note 1 . Both online batch modes are user-friendly versions of the original versions developed by Xiaofei Lu (see $\mathrm{Lu}, 2010,2012)$.

Note 2. The definitions of the production units and the syntactic structures used in the L2SCA software are explained in Lu's (2010, pp. 9-13) article.

Note 3. Since there is only one measure of lexical density, an increase in the construct would indicate an increase in the whole sub-construct and vice versa.

Note 4. In all of the measures of syntactic complexity, lexical density, sophistication, variation, fluency, and in only eight measures of accuracy (i.e., EFT, EFT/T, EFT/W, EFT/S, EFC/T, EFC/S, EFC/C, and EFC), an increase indicates an increase in the constructs/sub-constructs and a decrease shows a decrease in the constructs/sub-constructs. Yet, in the other measures of accuracy (i.e., E, E/T, E/W, E/C), there is a reversed result. The increase in these measures indicates a decrease in the construct, and a decrease shows an increase in the construct.

Note 5. For more details about Skehan and Foster's model, see Skehan and Foster (1997, 1999, 2001, 2005, 2012).

Note 6. Robinson's model is discussed in more detail in the following (Robinson, 2001a, 2001b, 2003, 2005, 2007, 2011a, 2011b, 2015; see also Baralt, Gilabert, \& Robinson, 2014; Robinson \& Gilabert, 2007). 
Appendix A

Textbook Cover Page

\section{The Researched Essay}
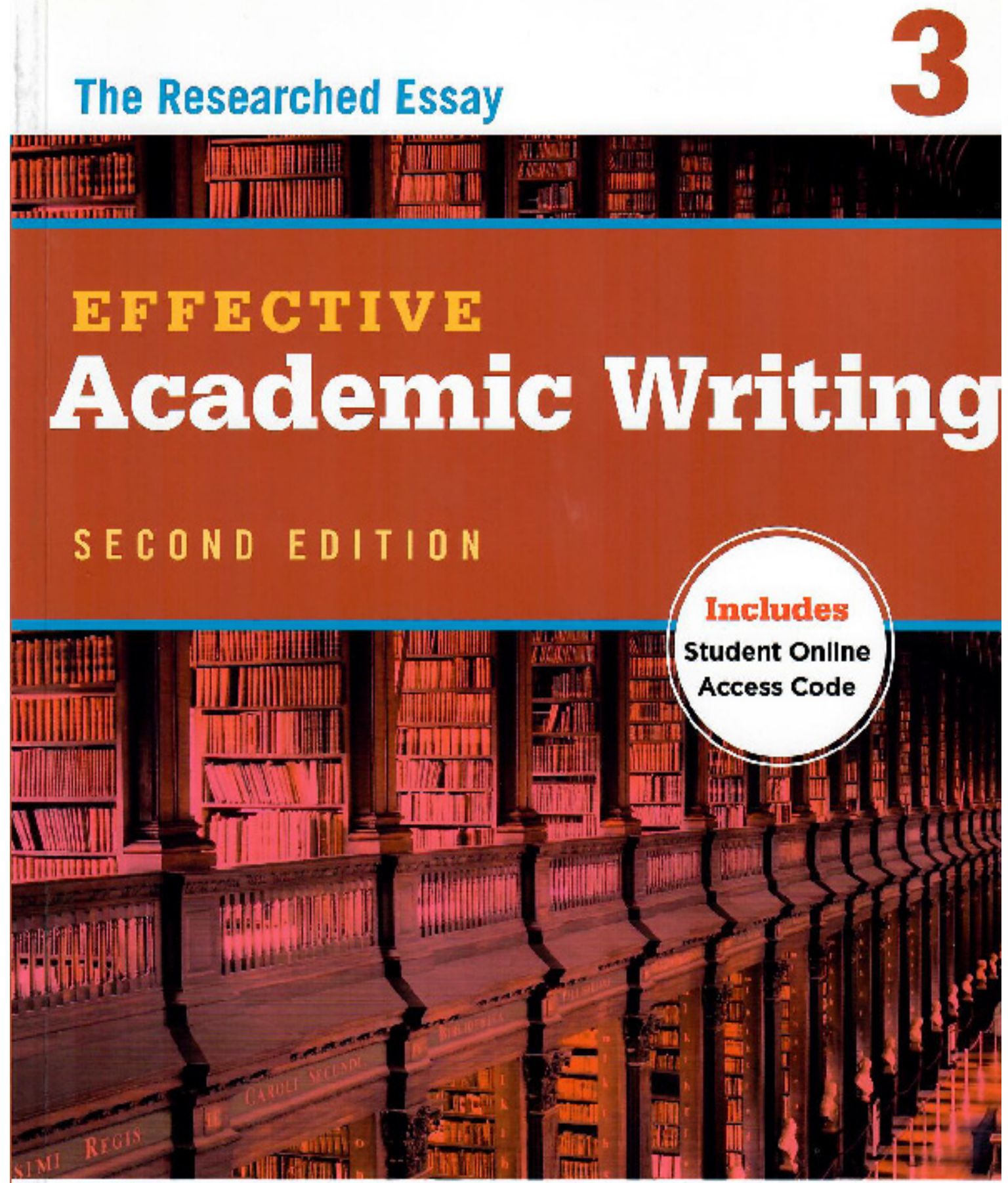

Rhonda Liss

Jason Davis

OXFORD 


\title{
Appendix B
}

\section{Writing Course Syllabus}

KINGDOM OF SAUDI ARABIA

Ministry of Hlgher Educatlon

Al-imam Muhammad Ibn Saud Islamic University

COLLEGTI OF LAVGLACINS \& TRAVSLATION

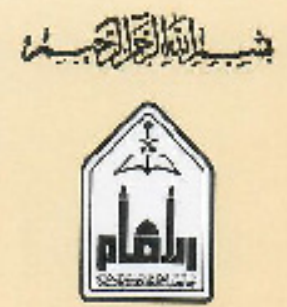

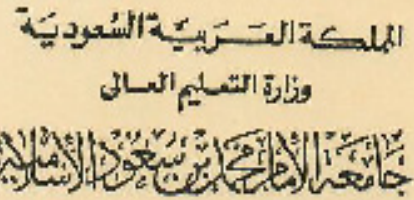

كلية اللغات والتزبهـ

Encls. :

المُمفوعات: Dut:

التبريخ: Ref. :

Writing Course Syllabus

\begin{tabular}{|c|c|}
\hline Caurve Code & Eng (3|6) \\
\hline LeFel and Year & I cuel 62019 \\
\hline Title & Essay Writing \\
\hline Tencher & $\ldots$ \\
\hline Credit Hours & 2 \\
\hline Pru-Requuivites & Essay' Writing (Eng.315) l.evel 5 \\
\hline Duration of Coursc & Is weeks \\
\hline Study Time & 30 hours \\
\hline
\end{tabular}

\begin{abstract}
Aim and $\quad$ This course licuses on the writing processes, genres (i.a, reaction.
Lemrning argumentative, and classification essaysi, and the concepts of audience,

Outcomes purpose, ard Form. The learning outcomes of the course are as follows:

1. Allow students to improve their effective writ ing strategies and skills.

2. Enable students to experiment writing varicus genres and rhetorical patterus 〈reaction, argumentative, and classification).

3. Anblyze ud how samplis on reaction, argumentat $x$, and classification for purpese. registcl, audience, wordri, expressions, phrases, sentences, firmat, style, gramma:, organiza:ion, elarily, punctuations, etc.

4. Identify mistakesierrors on format, grammar, spelling, style, clarity, organization. and punctuations.

5. Revise and adil in corter o substentially improve the lieus and development of idess, and convect the fomat, grummar, spelling, style, clarily, o:gunization. and punctuations.
\end{abstract}

\begin{tabular}{|c|c|}
\hline $\begin{array}{l}\text { Teaching/Learniug } \\
\text { Method and } \\
\text { Requirements }\end{array}$ & 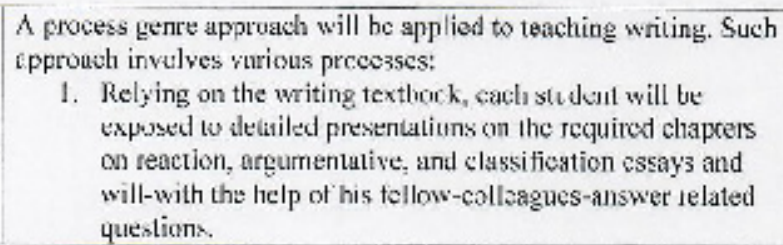 \\
\hline
\end{tabular}


KINGDOM OF SAUDI ARABIA

Ministry of Higher Education

Al-Imam Muhammad Ibn Saud Istamic University

WULLECT. OF LANGUAGES \& TRANSLAIIUN

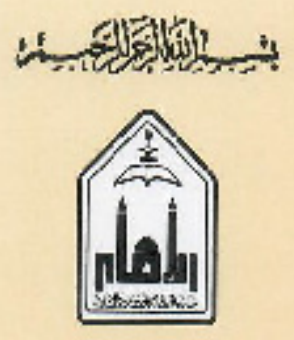

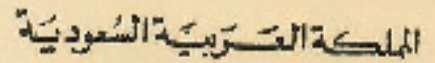

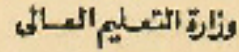

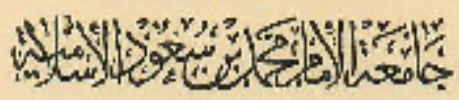

كلبة المانات والتربجه

Encls. : اللشنفوعاتي Date : : Ref. :

2. After explaining eash designsted chapter, an ad hoc s.mplo on reaction esistly, for examplc, will be provided to students. Students' lask is to read the sample and analyze it atecording to purpuse, repister, audience, words. phrases, expressions, sentences, formal, slyle, jrammar, organization, clarity, punctuations, etc.

3. Students may use the information they gathered from the samples when writing their writing assigments.

4. Students are tecplited to writc at home at: essay of 250 words the linst week of every group of five weeks (iec the following sestion). The firs drat: will be corrested by the leacher and onc of your fellow-colleagues. The sommants, corvelions, and suggestions provided should bo tuking into considerutions when writing the second, third, fourth, and sij on drufts at home. All following dralts should be submitted to my mailbox a day after receiving my corrections along with your fellow-colleagues'. All of such is appliceale to all text types.

\begin{tabular}{|c|c|c|c|}
\hline \multicolumn{4}{|c|}{ Study Plan, Requirements, Further Information, aud Distributiou of Murks } \\
\hline Week & Topic & & \\
\hline I & \multicolumn{3}{|c|}{ Course Oritnlation } \\
\hline 2 & \multicolumn{3}{|c|}{ Writing 1 (Pre-test) } \\
\hline 3 & \multirow{3}{*}{$\begin{array}{l}\text { Chapter G Reacrion } \\
\text { Fssays }\end{array}$} & \multirow{3}{*}{$\begin{array}{l}\text { Presentations, } \\
\text { anulyzing at } \\
\text { sumple, and } \\
\text { answeri.ig } \\
\text { qucstious }\end{array}$} & Writing draft 2 \\
\hline 4 & & & Writing druli 3 \\
\hline 5 & & & Writing drati 4 \\
\hline 6 & \multirow{5}{*}{$\begin{array}{l}\text { Chapler } 4 \\
\text { A"gumentative Essays }\end{array}$} & \multirow{5}{*}{$\begin{array}{l}\text { Presentations, } \\
\text { analyzing a } \\
\text { sumple, and } \\
\text { answering } \\
\text { questiors }\end{array}$} & Writing dre 11 \\
\hline 7 & & & Writing dratt 2 \\
\hline 8 & & & Wiriling draft : \\
\hline 9 & & & Wiriting drall 4 \\
\hline 10 & & & Writing draft 5 \\
\hline 11 & \multirow{3}{*}{$\begin{array}{l}\text { Chapte: } 5 \\
\text { Classificulion l'ssays }\end{array}$} & \multirow{3}{*}{$\begin{array}{l}\text { ['resentations, } \\
\text { analyzirg a } \\
\text { sample. and }\end{array}$} & Writiltg distl] \\
\hline 12 & & & Wriling drufl 2 \\
\hline 13 & & & Vititing draft 3 \\
\hline
\end{tabular}




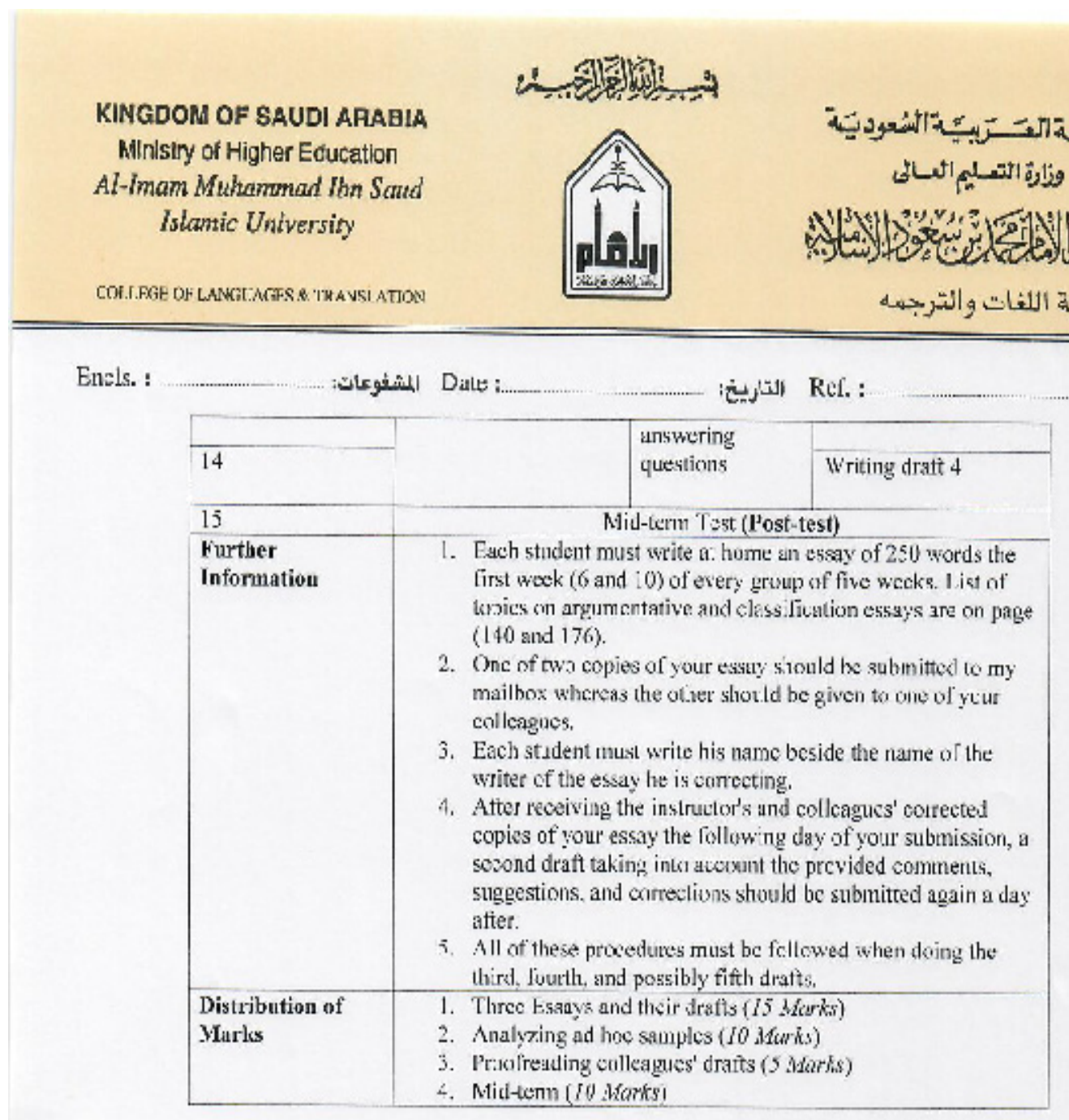

\section{Textbook}

Liss, R. and Davis, J. (2012). Fyfective Acadentic Hriting 3 (2 $2^{\text {nc }}$ ed.). Loncon: Oxlord

University Press.

Supplementary Paper and Electronic Materials

Gilbert J. \& Colenna, M. (2006). Reason To Write. Lendon: Oxford T.niversity Prese.

Hogue, Ann (1005), Fïrst Shepi in Academic Wrining. Lundun: Addison-Weslcy

Publishing Company, Ine

Smalloy, R.i., Ruetten, M. K. \& Kozyrsv J.R. (2000). Refining Commosition skil/s; Rhetoric and Granourer (5th cd.). Boston: I leinle \& I Jeinle l'ublishers.

hutps:;/writingeenter fas harvard.eduipages'strategies-exsuy-uriting.

htips:"ibowallcycollege.libgnides.comiessays

www.paragraphapunch.com

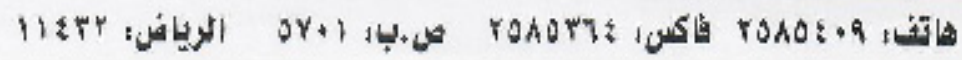




\section{Appendix C}

\section{Writing Skills Pre-Test}

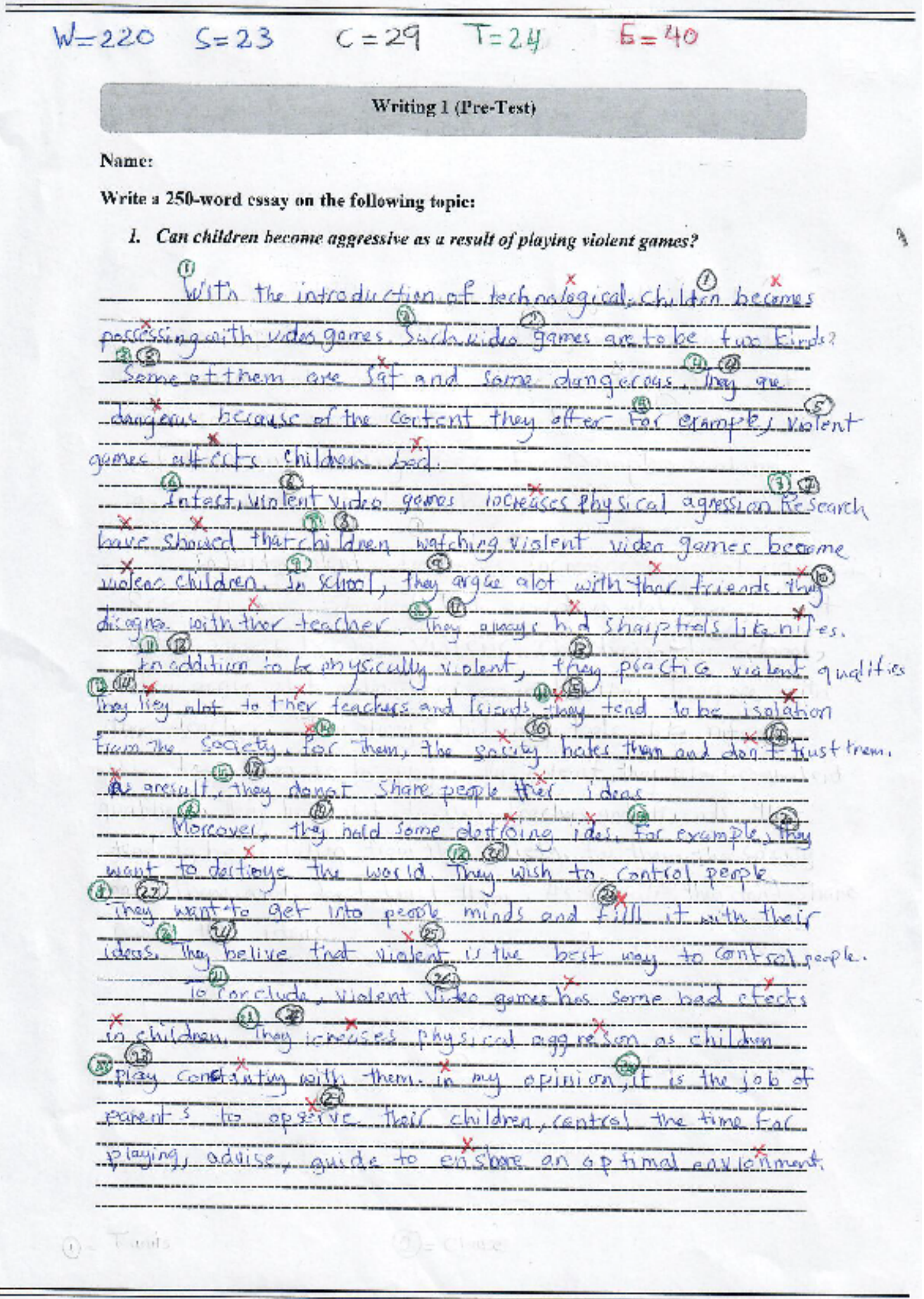




\section{Appendix D}

\section{Writing Skills Post-Test}

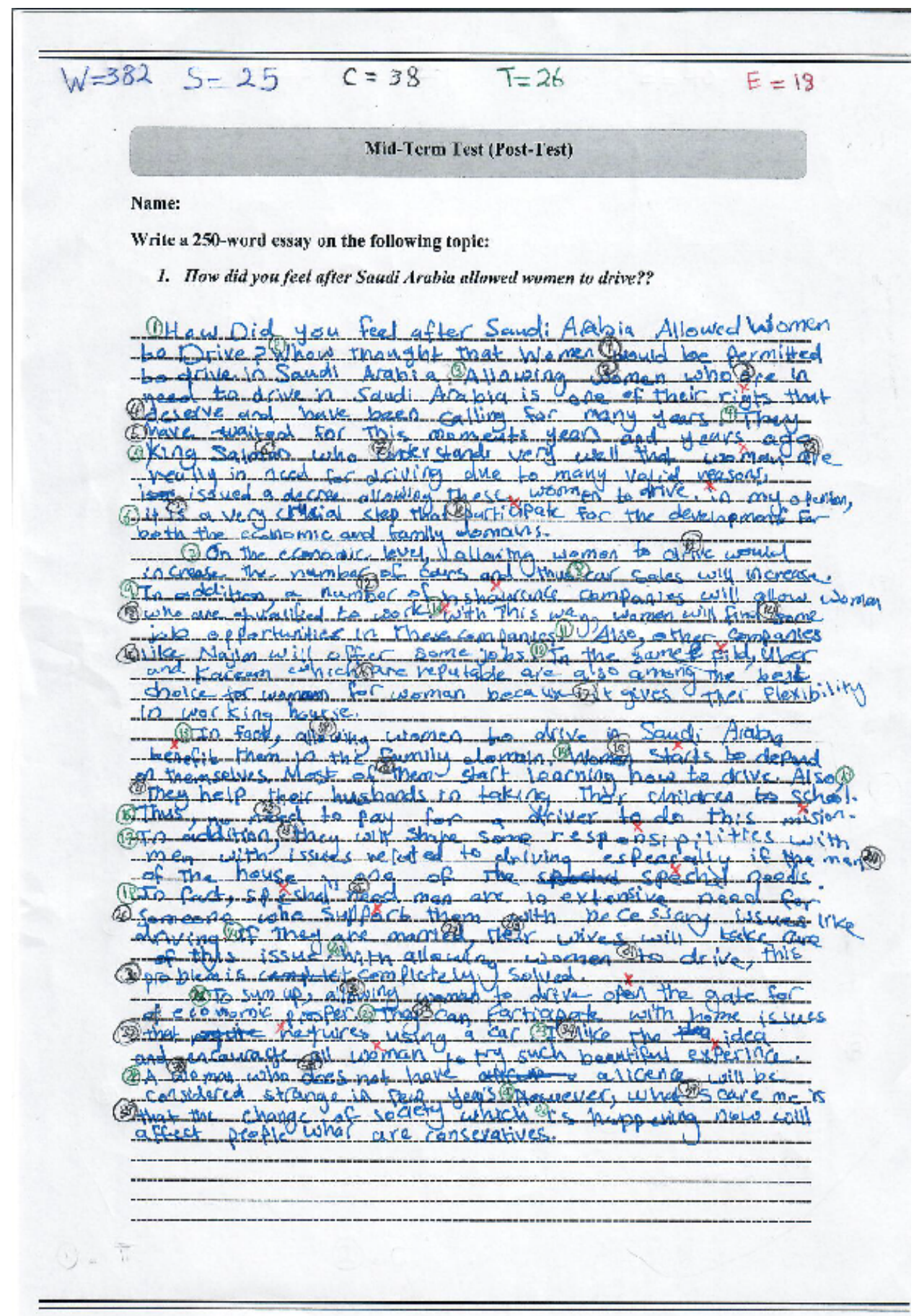

\section{Copyrights}

Copyright for this article is retained by the author, with first publication rights granted to the journal.

This is an open-access article distributed under the terms and conditions of the Creative Commons Attribution license (http://creativecommons.org/licenses/by/4.0/). 